NBER WORKING PAPER SERIES

\title{
HUMAN CAPITAL AND INDUSTRIALIZATION: EVIDENCE FROM THE AGE OF ENLIGHTENMENT
}

\author{
Mara P. Squicciarini \\ Nico Voigtländer \\ Working Paper 20219 \\ http://www.nber.org/papers/w20219
NATIONAL BUREAU OF ECONOMIC RESEARCH
1050 Massachusetts Avenue
Cambridge, MA 02138
June 2014

We would like to thank Ran Abramitzky, Quamrul Ashraf, Sascha Becker, Ruxanda Berlinschi, Leonardo Bursztyn, Davide Cantoni, Nick Crafts, Giacomo De Luca, Christian Dippel, Frédéric Docquier, Paola Giuliano, Avner Greif, Oded Galor, Noel Johnson, Mark Koyama, Stelios Michalopoulos, Joel Mokyr, Suresh Naidu, Nathan Nunn, Ahmed Rahman, Andrei Shleifer, Enrico Spolaore, Jo Swinnen, Joachim Voth, FabianWaldinger, JohnWallis, Ludger Woessmann, and Noam Yuchtman, as well as seminar audiences at Berkeley, Brown, IMT Lucca, IPEG Barcelona, KU Leuven, Northwestern, the NWO ClioInfra Workshop in Barcelona, SciencesPo, Stanford, the Strasbourg 10th BETA Workshop, UCLA, UC Davis, UC Louvain, the University of Munich, the Warwick in Venice conference, the WAEHS, and Wharton for helpful comments and suggestions. We are grateful to Petra Moser for sharing her data on exhibits at the 1851 Crystal Palace Exhibition, to Tomas E. Murphy for sharing digitized data of Annuaires Statistiques de la France, to Carles Boix for sharing data on proto-industrialization in France, to Jeremiah Dittmar for his data on ports and navigable rivers, to David de la Croix and Omar Licandro for their data on "famous" people, and to Daniel Hicks for geocoded data on soldier height. The views expressed herein are those of the authors and do not necessarily reflect the views of the National Bureau of Economic Research.

NBER working papers are circulated for discussion and comment purposes. They have not been peerreviewed or been subject to the review by the NBER Board of Directors that accompanies official NBER publications.

(C) 2014 by Mara P. Squicciarini and Nico Voigtländer. All rights reserved. Short sections of text, not to exceed two paragraphs, may be quoted without explicit permission provided that full credit, including (C) notice, is given to the source. 
Human Capital and Industrialization: Evidence from the Age of Enlightenment

Mara P. Squicciarini and Nico Voigtländer

NBER Working Paper No. 20219

June 2014,Revised March 2015

JEL No. J24,N13,O14,O41

\begin{abstract}
$\underline{\text { ABSTRACT }}$
While human capital is a strong predictor of economic development today, its importance for the Industrial Revolution has typically been assessed as minor. To resolve this puzzling contrast, we differentiate average human capital (literacy) from upper-tail knowledge. As a proxy for the historical presence of knowledge elites, we use city-level subscriptions to the famous Encyclopédie in mid-18th century France. We show that subscriber density is a strong predictor of city growth after the onset of French industrialization. Alternative measures of development such as soldier height, disposable income, and industrial activity confirm this pattern. Initial literacy levels, on the other hand, are associated with development in the cross-section, but they do not predict growth. Finally, by joining data on British patents with a large French firm survey from the 1840s, we shed light on the mechanism: upper-tail knowledge raised productivity in innovative industrial technology.
\end{abstract}

\author{
Mara P. Squicciarini \\ KULeuven - Department of Economics \\ Waaistraat 6, bus 3511 \\ Leuven, 3000 - Belgium \\ mara.squicciarini@kuleuven.be \\ Nico Voigtländer \\ UCLA Anderson School of Management \\ 110 Westwood Plaza \\ C513 Entrepreneurs Hall \\ Los Angeles, CA 90095 \\ and NBER \\ nico.v@anderson.ucla.edu
}

A data appendix is available at:

http://www.nber.org/data-appendix/w20219 
The genre of modern industrial production requires extended knowledge of mechanics, notion of calculus, great dexterity at work, and enlightenment in the underlying principles of the crafts. This combination of expertise ... has only been achieved in this [18th century] period, where the study of science has spread widely, accompanied by an intimate relationship between savants and artisans. (Chaptal, 1819, p.32)

\section{Introduction}

A rich literature documents an important role of human capital for economic development in the modern world. Schooling is a strong predictor of economic growth, ${ }^{1}$ and of per capita income at the national and regional level. ${ }^{2}$ Both theory and evidence explain these findings as worker skills facilitating technology adoption and innovation. ${ }^{3}$ In contrast, the role of human capital during the Industrial Revolution is typically described as minor. In Britain - the cradle of industrialization educational attainment was low and inessential for economic growth (Mitch, 1993). ${ }^{4}$ On the other hand, Scandinavia - which was fully literate as early as 1800 - fell behind and became Europe's "Impoverished Sophisticate" (Sandberg, 1979). Galor (2005, p.205) underlines that "in the first phase of the Industrial Revolution ... [h] uman capital had a limited role in the production process, and education served religious, social, and national goals." At a more systematic level, crosscountry growth regressions for the period of industrialization lead to the conclusion that "literacy was generally unimportant for growth" (Allen, 2003, p.433). The stark contrast to the findings in modern data is puzzling: did the escape from millennia of stagnation really occur without a role for one of the most important determinants of modern growth - human capital?

The previous non-results are based on education or literacy as skill measures of the average worker. This may veil the role of scientifically savvy engineers and entrepreneurs at the top of the skill distribution. Mokyr (2005a) stresses the importance of this "density in the upper tail," and Mokyr and Voth (2009, p.35) conclude that "the Industrial Revolution was carried not by the skills of the average or modal worker, but by the ingenuity and technical ability of a minority." Recent research on contemporaneous economies chimes in, underlining the importance of math and

\footnotetext{
${ }^{1}$ See Barro (1991) and Mankiw, Romer, and Weil (1992) for early empirical growth studies, and Krueger and Lindahl (2001), Barro (2001), Cohen and Soto (2007), and Hanushek and Woessmann (2008) for more recent confirmations based on richer data.

${ }^{2}$ Gennaioli, La Porta, Lopez-de-Silanes, and Shleifer (2013). While the role of human capital as a fundamental determinant of contemporaneous growth and development has been debated, its importance as a proximate cause, i.e., an essential input in the production function, is undisputed (Hall and Jones, 1999; Glaeser, La Porta, Lopez-de-Silanes, and Shleifer, 2004; Acemoglu, Gallego, and Robinson, 2014).

${ }^{3}$ C.f. Nelson and Phelps (1966), Benhabib and Spiegel (1994), Caselli and Coleman (2006), and Ciccone and Papaioannou (2009).

${ }^{4}$ As late as 1855, at the end of the first Industrial Revolution, primary-school enrollment in Britain was only 11\% (Flora, Kraus, and Pfenning, 1983). Also, modern technology typically replaced skilled craftsmen, and the skill premium remained unchanged until 1900 (Clark, 2005).
} 
science skills, or of entrepreneurial ability (Hanushek and Kimko, 2000; Bloom and Van Reenen, 2007; Gennaioli et al., 2013).

In this paper, we ask whether distinguishing between upper-tail and average skills may reinstate the importance of human capital during the transition from stagnation to growth. Answering this question hinges on a historical proxy for the thickness of the upper tail, i.e., the presence of knowledge elites. ${ }^{5}$ We use a novel measure from the eve of industrialization in mid-18th century France: subscriptions to the Encyclopédie, the cornerstone of the Enlightenment, representing the most important collection of scientific and technological knowledge at the time. This period saw the emergence of the knowledge economy, and the Encyclopédie was at its forefront (Mokyr, 2002). One of the publishers kept a list of all (more than 8,000) subscriptions to the most prominent edition. ${ }^{6}$ Based on this information, we calculate subscriber density for almost 200 French cities and use it as a proxy for the local concentration of knowledge elites. Figure 1 shows that regions with high and low values are relatively evenly distributed and often immediately adjacent. In addition, subscriber density is uncorrelated with literacy rates in the same period, allowing us to differentiate between average and upper-tail skills. ${ }^{7}$

We discuss the different roles of average worker skills and upper-tail knowledge in the context of technology diffusion during industrialization. Rich historical evidence suggests that upper-tail knowledge enabled entrepreneurs in manufacturing to keep up with advances at the technology frontier. ${ }^{8}$ This is in line with Nelson and Phelps (1966), who argue that advanced skills are particularly useful when technological progress is rapid. Put in a spatial context, this mechanism has two empirically testable implications for development (formalized in a stylized model in Appendix A): First, regions with a thick knowledge elite industrialize faster. Second, the effect of knowledge elites on local development becomes stronger when the aggregate technology frontier expands more rapidly, i.e., after the onset of the Industrial Revolution. Next, to illustrate the role of

\footnotetext{
${ }^{5}$ Following Mokyr (2005a), we use a broad definition of "upper-tail knowledge": it reflects an interest in scientific advances, motivated by the Baconian notion that knowledge is at the heart of material progress. This concept comprises not only innovative and entrepreneurial capabilities in adopting and improving new technology, but also lower access costs to modern techniques; it is thus compatible with Mokyr's notion of (economically) "useful knowledge." When referring to the local presence of people embodying such knowledge, we use the term "knowledge elite."

${ }^{6}$ While we know the cities at which these subscriptions were sold, the names of individual subscribers survived only in a few cases - where they did, a substantial share of subscribers were progressively minded and scientifically interested noblemen, administrative elites, and entrepreneurs.

${ }^{7}$ The fact that the two measures are uncorrelated is not astonishing, given that the knowledge elite was a tiny proportion of the overall population.

${ }^{8}$ This reflects that an interest in science helped entrepreneurs both to learn about new techniques in the first place, and to understand the underlying principles needed to implement and run them. A precondition for this mechanism is that knowledge about scientific advances and new technologies was not kept secret. This "open science" emerged during the period of Enlightenment, accompanied by the appearance of scientific and technical publications. In line with our argument, these "were without doubt of interest to only a small minority" (Mokyr, 2005b, p.300).
} 
average worker skills, suppose that these enter production in the standard labor-augmenting way. Then, better educated workers raise the productivity of any given technology, but they do not act as entrepreneurs, i.e., they do not adopt new technology. This leads to a third prediction: the level of worker skills affects income in the cross-section, but not growth over time. ${ }^{9}$ Using the growth accounting terminology by Jorgenson and Griliches (1967), higher worker skills lead to higher output by movement along a given production function, while upper-tail entrepreneurial skills can shift the production function, leading to higher output by raising total factor productivity.

We collect a host of outcome variables to test the above predictions. First, our main analysis uses city population in France as a proxy for development, following a series of papers in the tradition of DeLong and Shleifer (1993). As illustrated in Figure 2, subscriber density was strongly associated with city growth between 1750 and 1850 - the period of French industrialization. We also show that this relationship became stronger after the onset of industrialization, as compared to the pre-1750 period. ${ }^{10}$ Second, we use soldier height as a proxy for income at the French department level. We find that after 1820, soldier height is significantly associated with Encyclopédie subscriptions, while this relationship is insignificant before 1750. Third, mid-19th century census data for almost 90 French departments reveal that those with higher subscriber density had significantly higher disposable income as well as higher wages, employment, and output in industry. For all outcome variables, we also confirm the prediction that levels of literacy or schooling (proxying for average worker skills) are positively associated with development in the cross-section, but do not explain growth.

When interpreting our results, we do not argue that the Encyclopédie caused scientific knowledge at the local level. In fact, knowledge elites were present prior to 1750 , and their spatial distribution seems to have been relatively stable over time. We show that pre-1750 scientific societies are a strong predictor of subscriber density. The same is true for the share of Huguenots in 1670 - the suppressed Protestant minority typically associated with the French knowledge elite (Scoville, 1953; Hornung, 2014). In addition, locations with higher subscriber density brought up a larger proportion of "famous" people in scientific professions between the 11th and 19th centuries, and they also exhibited more innovations (per capita) at the 1851 World Fair in London. In short, the evidence suggests that subscriber density reflects a stable spatial distribution of knowledge

\footnotetext{
${ }^{9}$ Note that changes in worker skills at a given location over time will also raise income. Thus, the expansion of schooling raises income - although the initial level of literacy does not.

${ }^{10}$ This is not to say that upper-tail knowledge did not matter prior to the Industrial Revolution. During earlier episodes of economic expansion, advanced knowledge could also foster growth. For example, Cantoni and Yuchtman (2014) show that university-trained lawyers played an important role in the establishment of markets during the "Commercial Revolution" in medieval Europe, and Dittmar (2013) shows that during the same period, access to printed merchants' manuals led to faster city growth.
} 
elites. ${ }^{11}$ Our argument is that these elites fostered growth when knowledge became economically "useful," and technological progress became rapid. This follows Mokyr's (2002; 2005b) seminal work on the rising importance of upper-tail knowledge during the period of Industrial Enlightenment. Another publication of "useful knowledge" is the Descriptions des Arts et Métiers, a collection of French manufacturing knowledge in the 18th century. Its sales are highly correlated with Encyclopédie subscriber density, and are also strongly associated with growth.

To support our interpretation, we discuss detailed historical evidence that connects scientific knowledge to entrepreneurship and technological improvements, both via innovation and via the adoption of modern techniques. We further support our argument by providing systematic evidence for the mechanism from a survey of more than 14,000 French firms in 1839-47. Based on sector-specific British patent data, we split these firms into "modern" (innovative) and "old." We show that firms in modern (but not in "old") sectors were much more productive in regions with higher subscriber density, even after controlling for sector and location fixed effects. This suggests that upper-tail knowledge favored the adoption and efficient operation of innovative industrial technology.

We do not claim that upper-tail knowledge was necessarily a fundamental driver of economic growth during industrialization. ${ }^{12}$ The spatial variation in scientific knowledge may be due to deeper determinants such as culture, institutions, or geography, which could also affect growth via channels other than human capital. Correspondingly, we interpret upper-tail knowledge as a proximate driver of industrial growth, i.e., as a factor that influences the production function possibly in combination with other proximate determinants. Among the latter, physical capital is probably the most relevant in the context of our study: Encyclopédie subscribers typically came from the progressive bourgeoisie and nobility, who not only were part of the knowledge elite but also had access to finance. A critical challenge for our interpretation is thus: could financial means have been the dominant factor, while upper-tail knowledge was only a sideshow without economic relevance? Our results suggest that this is unlikely: subscriber density is not associated with growth before modern technology became available, and even thereafter, the presence of noble families (as a proxy for wealth) alone does not explain growth - it does only where noble families overlap with high subscriber density. In addition, the manufacturing sectors in which subscriber density

\footnotetext{
${ }^{11}$ In this dimension, our empirical analysis is similar in spirit to Voigtländer and Voth (2012), who take the spatial pattern of anti-Semitism as given and use historical persecution of Jews to measure it. The spatial dispersion of scientific activity in early modern Europe is well-documented (Livingstone, 2003). We take this pattern as given, and argue that subscriber density is a powerful proxy to capture it.

${ }^{12}$ The distinction of fundamental vs. proximate determinants of growth goes back to North and Thomas (1973). As discussed above, evidence abounds that human capital is a proximate driver of contemporaneous development, but whether it is also fundamental is debated (see the references cited in footnote 2).
} 
had the strongest effect depended less on costly power engines, and firm size in these sectors was not important for productivity. These points, in combination with the rich historical evidence on the importance of advanced knowledge suggests that deep pockets alone were not enough. Rather than being a competing factor, physical capital was complementary to upper-tail knowledge.

We also control for other factors that are related to knowledge and development. For example, total book sales per capita at the city level in the 18th century are strongly correlated with subscriber density, but they do not affect growth. To shed light on the role of institutions, we use the fact that the French Revolution occurred approximately at the mid point of our main period of analysis (1750-1850). We find that subscriber density was strongly associated with city growth under both regimes, despite their radically different institutions. ${ }^{13}$ Our results are also robust to controlling for geographic characteristics, pre-industrial activity, and the early presence of universities and printing presses. Taken together, the historical evidence in combination with our empirical findings renders it difficult to imagine that (upper-tail) human capital did not play a major role during industrialization.

Our paper is related to a large literature on the transition from stagnation to growth (for an overview see Galor, 2011), and in particular to the role of human capital during industrialization. For England - the technological leader - the predominant view is that formal education did not contribute to economic growth (Mokyr, 1990; Mitch, 1993; Crafts, 1996; Clark, 2005). For the follower countries, the evidence is mixed. O'Rourke and Williamson (1995) and Taylor (1999) conclude from country-level cross-sectional and panel analyses that human capital was not a crucial driver of economic catch-up in the 19th century. In contrast, Becker, Hornung, and Woessmann (2011) document that elementary education predicts employment levels in metals and other industries, but not in textiles in 19C Prussia. This is in line with O'Rourke, Rahman, and Taylor (2013), who emphasize that industrial innovation in sectors such as textiles was initially biased towards unskilled labor, reducing the demand for skilled workers. We shed new light on this debate by distinguishing between average and upper-tail skills, following Mokyr's (2005b) argument that the expansion and accessibility of "useful knowledge" during the Enlightenment was a cornerstone of industrial development. ${ }^{14}$ Our paper also relates to a literature showing that book production had

\footnotetext{
${ }^{13}$ In addition, after the 17 th century, France was a centralized absolutist state, allowing for relatively little local variation in institutions (Braudel, 1982; DeLong and Shleifer, 1993, see also the detailed discussion in Appendix E.1). Our analysis is thus less affected by the typical limitations of cross-country studies. We also control for regions where the king exerted particularly strong control - the pays d'élection - and find that these differed neither in subscriber density nor growth. Of course, this does not mean that institutions were unimportant for the Industrial Revolution - in particular, in the cross-country dimension they may be an important factor behind Britain's lead (North, 1981). However, given the above arguments, it is unlikely that unobserved institutions confound our results within France.

${ }^{14}$ Kelly, Mokyr, and Ó Gráda (2014) also emphasize the importance of highly skilled, technically capable individuals. In the contemporaneous context, Hanushek and Woessman (2012) show that the share of cognitively high-
} 
a positive impact on pre-industrial economic development (Baten and van Zanden, 2008; Dittmar, 2011). ${ }^{15}$ Our main explanatory variable, Encyclopédie subscriber density, offers two advantages over printing locations or local book production. First, it is a more precise measure, identifying readers within the narrow category of scientific publications. ${ }^{16}$ Second, subscriptions measure the local demand for knowledge, rather than the supply of books from printing locations.

Relative to this literature, we make several contributions. To the best of our knowledge, this paper is the first to empirically differentiate between average worker skills (literacy/schooling) and upper-tail knowledge during the Industrial Revolution. Along this dimension, our study is the first to provide systematic evidence for Mokyr's (2005b) hypothesis about the importance of "useful knowledge" for industrialization. We also shed light on the mechanism, showing that upper-tail knowledge probably fostered growth by raising firm productivity in modern, innovative industries. Finally, we show that the level of literacy was related to economic development in the cross-section, but - in contrast to upper-tail knowledge - not to growth. Thus, the role of literacy during industrialization is best captured by the Mincer model (where change in schooling leads to growth), while upper-tail knowledge fits the setup in the empirical macro growth literature, which typically specifies growth as a function of initial human capital (Krueger and Lindahl, 2001).

The paper is organized as follows: Section 2 reviews the historical background of industrialization in France with particular emphasis on the intersection of science and entrepreneurship. We also discuss Encyclopédie subscriptions as a proxy for the presence of knowledge elites, and the channels via which upper-tail knowledge affected economic growth. In Section 3 we describe the data, and Section 4 presents our main empirical results. Section 5 provides evidence on the mechanism, interprets our results, and discusses their limitations. Section 6 concludes by discussing the implications of our findings for the literature on human capital and development.

\section{The Age of Enlightenment: Industrialization and Human Capital}

The Enlightenment was a period of intellectual and cultural revolution in Western history that many consider a cornerstone for the onset of modern economic growth (c.f. Jacob, 1997). The Age of Enlightenment stretched from the late 17th through the 18th century, stressing the impor-

performing students is strongly associated with growth, independent of basic literacy.

${ }^{15}$ Baten and van Zanden show for a panel of eight European countries over the period 1450-1850 that wage growth was more rapid where book printing was more pronounced. Remarkably, however, after 1750 countries with particularly high volumes of book printing, such as Sweden and the Netherlands, saw a decline in real wages. This suggests that the observed pattern is driven by variation before the onset of industrialization.

${ }^{16}$ Total book production, in contrast, contains books from cooking manuals to religious works. For example, books about natural science, math, and engineering account for less than $5 \%$ of overall book sales by the large publishing house STN in the late 18th century, while $70 \%$ of all sales occurred in Belles lettres (e.g., novels and poetry), history, and religion (FBTEE, 2012). 
tance of reason and science, as opposed to faith and tradition. Despite its efforts to popularize and spread knowledge, the Enlightenment never became a mass movement; it remained confined to a small elite. Nevertheless, it played a crucial role in fostering industrial development and economic growth, both through the expansion of propositional knowledge with practical applications, and through a reduction of access costs to existing knowledge. In this context, Mokyr (2005a, p.22) refers to the Industrial Enlightenment, which "bridged between the Scientific and Industrial Revolution."

In the following, we describe the tight link between upper-tail knowledge and industrial growth during this period. While the Industrial Revolution originated in Britain, the positive interplay between science and industry was also widespread on the continent, in particular in France. We provide background on the industrialization in France and discuss why it presents an exemplary setting to empirically test the relationship between upper-tail knowledge and economic growth. In addition, we describe the publishing history of the Encyclopédie, and why its subscriptions are a good proxy for the local presence of knowledge elites.

\subsection{Industrialization in France}

French economic growth began to accelerate in the mid-18th century; its industrial output more than doubled until 1800 (Rostow, 1975), and mechanization slowly began in textiles and metallurgy, the main industrial sectors (Daudin, 2005). ${ }^{17}$ France lagged behind England, where incomes started to rise steadily after 1670 (Broadberry, 2013). Nevertheless, on the eve of the French Revolution in 1789, per capita incomes in the two countries were probably not far apart (O'Brien and Keyder, 1978). Similarly, Horn (2006, p.10) argues that "[i]n an astonishing number of sectors, French entrepreneurs of the 1780s competed successfully with their English counterparts." And focusing on the demand side, Daudin (2010) shows that French domestic markets were already relatively integrated in the 18th century, allowing for specialization in production and thus efficiency gains. The French Revolution and the Napoleonic wars caused a slowdown in French growth until 1815, resulting in France lagging behind Britain by about a generation. ${ }^{18}$ The slowdown was followed by a prolonged period of strong economic performance until the mid-19th century. On average, French GDP per capita grew as fast as its British counterpart from 1820 to 1913, although

\footnotetext{
${ }^{17}$ Appendix C.1 provides further discussion and data showing that GDP per capita was relatively stable until approximately 1750, and then started to grow steadily. Timing the French industrial takeoff is difficult, as it lacks a clear structural break (Roehl, 1976); the predominant "moderate revisionist" view describes steady growth starting around 1750 until the mid-19th century, only interrupted during the two decades after the revolution in 1789 (Crouzet, 2003).

${ }^{18}$ The most damaging factor of the war was not destruction of capital, but reduced trade and access to knowhow because of the British maritime blockade (Crouzet, 1964). The slower rate of growth (wrongly) prompted some historians to "derogate the economic development of France as a story of retardation or relative backwardness" (O'Brien and Keyder, 1978, p.194).
} 
French population grew at a markedly slower rate (Maddison, 2001). In his comparison of the two countries, Crouzet (2003, p.234) concludes that "[a]ltogether, it is widely accepted that France followed its own specific path to industrialization, which was different from the British way, but not necessarily inferior."

Scientific knowledge played an important role during industrialization in both Britain and France. For the former, Dowey (2014) shows that scientific societies were strongly associated with technological innovation during the Industrial Revolution, and Jacob (2014, pp.92-94) stresses that advanced knowledge was also crucial for using these innovations: entrepreneurs had to "make technological decisions with immediate economic consequences," for example, "installing the wrongsized engine could spell financial disaster." ${ }^{19}$ France, in its role as a follower country, initially depended largely on the adoption of British technology. ${ }^{20}$ British knowhow reached France via several channels. Scientific reports published and studied by learned societies played an important role, in combination with an intense correspondence between "industrially minded" people in the two countries (Mokyr, 2005b). In addition, industrial spies sent regular reports on English technology (Harris, 1998). Progressive French producers imported English machines - often illegally, to avoid British export restrictions; they also hired thousands of British workers specifically to gain access to technical knowhow (Horn, 2006). Finally, French state and provincial governments supported scientific institutions, bringing together entrepreneurs and scientists; they also fostered the adoption of machines and expertise from abroad. These policies were put into practice at the national and local level by a commercial, industrial, and scientific elite (Chaussinand-Nogaret, 1985; Horn, 2006).

After its initial dependence on British techniques, France increasingly became an important source of innovations itself. An early example is the father of the chemical revolution, Antoine Lavoisier, whose discoveries led to important industrial applications and affected the chemical industry all over Europe (Mokyr, 2005b). As French industrialization advanced, "technological progress became indigenous, built in to the economy, so that ... France became at mid[19th]century a centre of invention and diffusion for modern technologies" (Crouzet, 2003, p.234).

Industrialization was not spread evenly across France, which is salient for our study. Both wages in industry and employment shares showed substantial heterogeneity across departments in

\footnotetext{
${ }^{19}$ Alternative explanations for the Industrial Revolution have stressed the importance of coal (Wrigley, 1988; Pomeranz, 2000), or the relatively high wages in pre-industrial Britain as a reason for switching to capital-intensive production (Allen, 2006). Some authors have also argued that practical, as opposed to scientific, knowledge was crucial for technological progress during the Industrial Revolution (Mathias, 1972, see also our discussion in Section 2.4).

${ }^{20}$ Interestingly, France had arguably been ahead of Britain in terms of propositional (theoretical) knowledge at the eve of industrialization. However, when it came to mapping this into technologically useful (prescriptive) knowledge, Britain took the lead. French authorities soon recognized the importance of technical knowledge and tried to promote its spread by establishing engineering schools and organizing industrial expositions (Mokyr, 2002, ch.2).
} 
the mid-19th century (see Figures C.2 and C.3 in the Appendix). We exploit this spatial dispersion of economic activity - together with the spatial heterogeneity of knowledge elites - in our empirical analysis. This rich variation within France, together with the historically documented interaction between scientific knowledge and entrepreneurship (see Section 2.3 for further detail), makes France an excellent setting to study the role of upper-tail knowledge during industrialization.

\subsection{The Encyclopédie and Upper-Tail Knowledge}

In the culturally vibrant atmosphere of 18th century France, Diderot and d'Alembert launched the ambitious project of the Great Encyclopédie - the "most paradigmatic Enlightenment triumph" (Mokyr, 2005b, p.285). Following Lord Francis Bacon's conceptual framework, Diderot and d'Alembert's objective was to classify all domains of human knowledge in one single source, easily accessible to everybody. The focus was on knowledge derived from empirical observation, as opposed to superstition. While mercantilistic ideas were still widespread, and artisans and guilds kept secrecy over knowledge, a small elite believed that scientific knowledge should not be a private good, but disseminated as widely as possible (Mokyr, 2005a).

The Encyclopédie went through several editions and reprints. The government initially refused to allow official sales, and most copies went to customers outside of France. Correspondingly, the first and the second editions together sold only 3,000 copies in France. Moreover, the first two editions were luxury items that did not penetrate far beyond the restricted circle of courtiers, salon lions, and progressive parlementaires. This changed radically with the Quarto (1777-79) and the Octavo editions (1778-1782). ${ }^{21}$ Since our proxy for local knowledge elites is based on subscriptions to the Quarto, we discuss this edition in more detail. ${ }^{22}$

\section{The Quarto edition}

The Quarto edition of the Encyclopédie is particularly useful as a proxy for local knowledge elites for several reasons. It represents the turning point when the Encyclopédie moved to a phase of diffusion of Enlightenment on a massive scale. The Quarto was designed to be affordable for middle-class readers. Its format was smaller than the luxurious folio of Diderot, the quality of the

\footnotetext{
${ }^{21}$ The names Quarto and Octavo refer to the printing format: A Quarto sheet is folded twice, creating four leaves; an Octavo is folded three times, creating eight leaves. The central figure behind the Quarto edition was the French entrepreneur Charles-Joseph Panckoucke (1736-1798), who had bought the plates of the Encyclopédie from the original publishers, together with the rights to future editions. Administrative obstacles in selling the Quarto appear to have been minor. While the Encyclopédie was officially illegal until 1789, the government had relaxed its censorship. In addition, Panckoucke had good connections with the government and did not hesitate to lobby and bribe public officials (Vogt, 1982).

${ }^{22}$ The Quarto edition comprised 36 volumes of text and three volumes of illustrative plates. Since these were typically not delivered in one chunk, readers of the Encyclopédie are commonly referred to as "subscribers."
} 
paper poorer, and the price lower. The publishers described their price discrimination strategy as follows: "The in-folio format will be for "grands seigneurs" and libraries, while the in-quarto will be within the reach of hommes de lettres and interested readers [amateurs] whose fortune is less considerable." 23 The Quarto cost only one-fifth of the first original folio and was well within the reach of the middle class (although its price of 384 livres - about 26 weeks' wages for locksmiths or carpenters - was still unaffordable to lower social classes and workers). The pricing strategy proved extremely successful: scientific interest rather than deep pockets determined subscriptions to the Quarto, and it had the highest sales in France among all editions.

Crucially for our study, one of the publishers, Joseph Duplain, secretly kept a list of subscriptions, which survived in the archives of the Société Typographique de Neuchâtel (STN). This list contains the name of booksellers (but not subscribers), their city, and the number of sets they purchased for retail among their local clients. Darnton (1973) provides this list, which comprises 8,011 subscriptions, of which 7,081 were sold in France, in 118 cities. $^{24}$

\section{Subscriptions to the Quarto edition and local knowledge elites}

Does a higher frequency of subscriptions at a given location reflect a broader interest in upper-tail knowledge ${ }^{25}$ While Duplain's list does not allow for a systematic analysis of individual subscribers to answer this question, some information is available. For Besançon, a list of 137 subscribers has survived. Darnton (1973, p.1350) summarizes these by profession and social status: $11 \%$ belonged to the first estate (clergy) and $39 \%$ to the second estate (nobility); the remaining $50 \%$ belonged to lower social ranks, including the bourgeoisie. ${ }^{26}$ For example, professionals, merchants, and manufacturers account for $17 \%$ of the total. Thus, an important share of subscribers can be directly identified as economic agents (from lower ranks) involved in French industrialization. Their share is likely a lower bound for the importance of the Encyclopédie in the business community, because many subscribers in the upper class (nobility) were also active businessmen (Horn, 2006). ${ }^{27}$ For example, Chaussinand-Nogaret (1985, p.87) argues that

\footnotetext{
${ }^{23}$ Société Typographique de Neuchâtel (the publisher) in a letter to Rudiger of Moscow, May 31, 1777; cited after Darnton (1973, p.1349).

${ }^{24}$ Lyon with 1,078 and Paris with 487 subscriptions are at the top of this list; at the opposite end of the spectrum, there are 22 towns with fewer than 5 subscriptions. Subscriptions were not confined to major cities; instead, they were distributed across the whole French territory (see Figure 1).

${ }^{25}$ For example, it is possible that wealthy people merely bought the Encyclopédie to decorate their bookshelves. However, according to Darnton (1973, p.1352), if anything, the opposite was probably the case: "Far more people must have read the Encyclopédie than owned it, as would be common in an era when books were liberally loaned and when cabinets litteraires were booming."

${ }^{26}$ This may be a lower bound for other locations. The second estate is probably over-represented in this sample Besançon was a garrison town, and almost half of the subscriptions in this category went to noblemen in the army.

${ }^{27}$ This reflects the revisionist view that replaced earlier - often Marxist - interpretations of the nobility exemplifying an aristocratic tyranny of arrogance and decadence. An impartial reading of the historical account shows that "nobles
} 
Over a whole range of activities and enterprises nobles, either alone or in association with members of the greater business bourgeoisie, showed their dynamism, their taste for invention and innovation, and their ability as economic leaders: ... their ability to direct capital..., to choose investments according to their productiveness and their modernity, and ... to transmute the forms of production into an industrial revolution.

It is, however, important to note that only a progressive subset of the nobility was involved in industrial activities. ${ }^{28}$ The same subset was also heavily engaged in the Enlightenment (ChaussinandNogaret, 1985, p.73).

In addition, many subscriptions went to high public officials and parlementaires - about $28 \%$ of the total in Besançon. Enlightened elites in the provincial administration were often involved in fostering local industrialization. For example, in Rouen and Amiens, they established the Bureau of Encouragement that gathered businessmen, manufacturers, local savants, and provincial authorities in an effort to assist technological advance (Horn, 2006, p.81). Finally, the Encyclopédie - and especially the Quarto - also reached non-subscribers in the lower ranks of society, via indirect access (Roche, 1998). Organized lectures, symposia, and public experiments were booming in France during the Enlightenment, and public readings of the Encyclopédie were organized by scientific societies, libraries, lodges, and coffeehouses (Darnton, 1979; Mokyr, 2005b).

In sum, the Encyclopédie had a broad spectrum of readers from the knowledge elite who were directly and indirectly involved in industrialization. This supports both our use of subscriber density as a proxy for local upper-tail knowledge and the hypothesis that this knowledge was crucial in fostering economic growth. ${ }^{29}$ Next, we discuss a number of concrete examples for how scientific knowledge affected entrepreneurial activity and technological growth in France during its industrialization.

\subsection{Scientific Knowledge and Entrepreneurship}

There are many prominent examples for the link between upper-tail knowledge and entrepreneurship in 18th and 19th century France. Among the pioneers was René Antoine Ferchault de Réaumur (1683-1757), a mathematician and physicist who introduced the Réaumur thermometer scale, made crucial discoveries in iron and steel (such as the method of tinning), and was an important contributor to the Descriptions des Arts et Métiers. The outstanding chemist Antoine Lavoisier

of the eighteenth century had been as modern and progressive as anyone" (Smith, 2006a, p.2).

${ }^{28}$ As Chaussinand-Nogaret (1985, p.90) puts it: "In the economic sphere, ...it is clear that the whole of nobility was not involved, but only the part that can be considered its natural elite, ... because of its ... openness to the progressive tendencies of the age."

${ }^{29}$ Certainly, reading or hearing about a new technology was not sufficient to be able to adopt and operate it. However, scientific publications and lectures made technological knowhow available on a large scale, breaking the exclusive transmission from master to apprentice (Mokyr, 2005b). The details needed for actual adoption of new technologies were then often found elsewhere, such as embodied in "imported" British experts (see Section 2.4). 
(1743-1794), was educated in the spirit of Enlightenment, and fascinated by the Dictionnaire de Chymie (published in 1766). He worked on several applied problems such as the role of oxygen in combustion and street lighting, and he predicted the existence of silicon. Alexandre Vandermonde (1735-1796), a mathematician attracted to machinery and technology, fostered the first major industrial application of Lavoisier's chemistry in iron production (Mokyr, 2005b). Similarly, the chemist Claude Louis Berthollet (1748-1822) experimented with chlorine, discovering new methods for bleaching. His results were both published in scientific journals and applied in most of the leading textile-manufacturing firms of France. These discoveries led the contemporaneous observer Robert O'Reilly (an Irishman living in Paris) to declare in 1801: “A complete revolution in the art of bleaching...we have finally arrived in an époque where science and industrial arts, reinforcing each other, rapidly spill indefinite improvements" (cited after Musson and Robinson, 1969, p.253; our translation). Another example is the Duke d'Orléans, who set up a soda-making facility together with the chemist Nicolas Leblanc (1742-1806). He invested in several textile firms, adopting modern machinery from Britain, and introduced steam engines into cotton spinning in France (Horn, 2006; Chaussinand-Nogaret, 1985).

In other cases, the same person or family was involved in both scientific research and industrial activities. For instance, Jean-Antoine Chaptal, a famous chemist, successful entrepreneur, and political figure, considered science to be inseparable from technology, and the key to foster industrial development. He was well-connected in the French network of savants, which entertained an intensive exchange with international scientists such as James Watt, and stimulated the application of science to industry in France. Chaptal pursued this cause both as a public figure and as a private entrepreneur. As a public official, he created favorable economic and bureaucratic conditions for entrepreneurs, for example by founding the Conseils d'Agriculture, des Arts et Commerce, and the Société d'Encouragement pour l'Industrie National, where scientists, industrialists, and bureaucrats were brought together. He also subsidized promising artisans, engineers, and industrialists, and gave public lectures on chemistry and experimental physics. As a private entrepreneur, Chaptal built the largest factory for chemical products in France (Horn and Jacob, 1998).

In many cases, entrepreneurial dynasties with scientific spirit came from the Protestant minority - the Huguenots. For example, the Koechlin and Dollfus families in Mulhouse were closely related by intermarriage and descended directly from the famous mathematician Bernouilli. They ran prosperous firms in cotton and wool spinning, and founded the first cloth-printing firm in France. Some members also entered other industrial businesses, such as the manufacturing of textile machineries, locomotives, and railroad equipment. Their dynasties kept marrying other scientific families (most prominently, the Curies and the Friedels) and produced successful scientists themselves, such as Daniel Dollfus-Ausset (1797-1879), a chemist who made major innovations in 
bleaching while running his own textile firm (Hau, 2012; Smith, 2006b). A similar example is the famous chemist Michel Eugène Chevreul (1786-1889), who was born in Angers to a dynasty of surgeons with strong scientific ties. Chevreul made pathbreaking discoveries with important industrial applications such as soap production and dyeing. At the same time, he was directly involved in industrial production as the director of dyeing at the tapestry works at Gobelin and Beauvais, and at the carpet factory of Savonnerie (Lemay and Oesper, 1948).

Even in raw material production such as silk growing, scientific studies played an important role. The silkworm is extremely sensitive to cold, heat, and drafts, which rendered its adoption in France difficult. To tackle this problem, the entrepreneur Camille Beauvais built a model silk farm near Paris and hired the distinguished chemist d'Arcet for scientific support. They discovered innovative methods that raised worm productivity enormously, more than doubling output per egg, and allowing for four harvests per year (Barbour and Blydenburgh, 1844, p.39). Beauvais trained young growers at his farm, who spread his methods throughout France and eventually to the United States. His work was promoted and advertised by scientific organizations, such as the Société d'Encouragement pour l'Industrie Nationale.

These examples illustrate that the effect of knowledge elites on local industrial development could result from the dialogue between scientists and entrepreneurs, from scientifically savvy public officials supporting entrepreneurship, and from members of the elite themselves operating businesses.

\subsection{Worker Skills in Industrialization}

Having discussed the importance of entrepreneurs and innovators, we now turn to the role of worker skills. In the context of the Industrial Revolution, it is useful to distinguish between three skill categories: unskilled workers (e.g., miners and farm- or factory workers), skilled workers (who had acquired at least some skills, such as cutlers, glaziers, and tailors), and high-quality craftsmen at the very top of the worker skill distribution (engineers, instrument makers, and mechanics). ${ }^{30}$ To proxy for the division between skilled and unskilled workers, we use literacy rates a popular measure of human capital in the historical context (c.f. Mitch, 1993; Becker et al., 2011). This is motivated by the historical evidence in Houston (1982) and Nicholas and Nicholas (1992), who show that medium- and high-skilled professions had much higher literacy rates than unskilled ones. The overall pattern shows a "clear hierarchy of literacy rates by occupation" (Mitch, 1993,

\footnotetext{
${ }^{30}$ These categories are based on de Pleijt and Weisdorf (2014), who code the occupations of more than 30,000 workers in 16th-19th century Britain, using the Historical International Standard Classification of Occupations (HISCO). De Pleijt and Weisdorf use two categories for workers with at least some skills; we combine these into our "skilled" category. In the 18th century, the unskilled category accounted for about one-third of the workforce, and the skilled category for most of the remainder, while high-quality craftsmen were a very small proportion.
} 
p.291), reflecting that schooling or literacy of workers facilitated climbing the professional skill ladder. $^{31}$

However, literacy (or schooling) cannot differentiate the third category (high-quality craftsmen) from the relatively large group of skilled workers, because both types were typically literate. The tacit high-quality skills needed to install, operate, and maintain industrial machines were mostly transmitted via master-apprentice relations. This system was particularly well-developed in Britain, whose endowment with highly capable engineers, mechanics, and tool-makers ("implementers") was one of the reasons for its head start (Kelly et al., 2014). Quantifying this skill group for our empirical analysis is not possible - systematic cross-sectional data on apprenticeships in France is not available. However, there are several reasons to believe that the local presence of these implementers of technology coincided with the presence of inventors and entrepreneurs, i.e., those captured by our proxy for knowledge elites. First, there was a strong complementarity between these forms of technological activity - adoption and innovation by the latter needed the practical skills of the former (Meisenzahl and Mokyr, 2012). Second, inventors and entrepreneurs such as Boulton and Watt typically trained workers themselves in the skills needed to handle industrial machinery (Jacob, 2014). And in France, which initially lacked high-quality craftsmen, progressive entrepreneurs hired them from Britain: in the early 19th century, more than 10,000 English artisans - many of them engineers and mechanics - worked in France (Kelly et al., 2014). Their tacit skills were passed on to French workers, so that in effect, avant-garde French entrepreneurs created their own local supply of high-quality skills. ${ }^{32}$ Third, the implementers were a small elite: even in Britain, with its relative abundance of high-quality craftsmen, they accounted for less than $5 \%$ of the workforce (de Pleijt and Weisdorf, 2014) - and this is an upper bound estimate, counting all workers in the corresponding professions (i.e., not only those with very high ability). Within this group, Enlightenment was deeply rooted: more than one-half in a sample of 759 implementers collected by Meisenzahl and Mokyr (2012) were members in scientific societies and/or published about their technological discoveries. These points suggest that our proxy for the presence of enlightened elites also reflects at least some of the spatial variation in top-quality craftsmen.

\footnotetext{
${ }^{31}$ Dunham (1955, p.184) provides similar (anecdotal) evidence for France, describing how the lack of education affected French iron manufacturing: "Workers were ignorant, frequently illiterate, and consequently most reluctant to learn new methods." Conversely, this suggests that literacy promoted skill acquisition. Of course, this does not mean that there was a one-to-one mapping between literacy and skilled professions; however, there was an overlap that justifies the use of literacy as a proxy for worker skills.

${ }^{32}$ For example, Fox (1984, p.143) describes the case of the Risler brothers, who founded the first machine-building firm in southern Alsace. To implement advanced British technology, they hired the engineer Job Dixon from Manchester. The firm subsequently became the main supplier of the latest spinning and weaving machinery for the region, serving also as a training ground for French engineers. Fox (1984, p.142) also points out that "the French learned quickly, and as soon as local workmen had acquired the basic skills, the senior British operative became more of a rarity."
} 
Summing up, since the proportion of high-quality craftsmen was tiny in France, this category is unlikely to systematically affect regional literacy rates. Hence, literacy approximates the line between the remaining (much larger) skill categories - skilled and unskilled workers. On the other hand, we use Encyclopédie subscriber density to proxy for the cross-sectional distribution of highly skilled implementers at the top of the worker skill distribution. It is important to note that this measure serves as a pars pro toto, reflecting the local presence of enlightenment elites more broadly. We show below that subscriber density correlates strongly with other measures for upper-tail human capital, such as sales of the Descriptions des Arts et Métiers - a closer proxy for the presence of top-notch engineers and mechanics.

\section{Data}

In this section we describe our data. We begin with our main city-level dataset and then turn to department-level variables that reflect French development before, during, and after industrialization. Finally, we analyze whether our main explanatory variable - subscriber density - varies systematically with other local characteristics.

\subsection{City Dataset and Subcriber Density}

Our main dataset is constructed from the city population data by Bairoch, Batou, and Chèvre (1988). This panel includes cities that reached (at least once) 5,000 inhabitants between 1000 and 1800; it reports city size for every 100 years until 1700, and for every 50 years thereafter until 1850. We use those 193 French cities for which Bairoch et al. report population in 1750 - the year closest to the publication of the Encyclopédie. Matching the 7,081 subscriptions in France reported by Darnton (1973) to the data by Bairoch et al. (1988), we identify 85 cities with abovezero subscriptions. ${ }^{33}$ Since our data covers the universe of subscriptions, it is reasonable to assume that the remaining 108 cities in Bairoch et al. had zero subscribers. ${ }^{34}$

In the following, we use Subs to denote the number of subscribers in a city. Because larger cities will mechanically tend to have more subscribers, we normalize subscriptions by population in 1750. Subscriptions per capita (among cities with above-zero entries) varied substantially, from 0.5 per 1,000 in Strasbourg to 16.3 in Valence; Paris belonged to the lower tercile of this distribution, with 0.85 subscriptions per $1,000 .{ }^{35}$ To reduce the influence of extreme values, we

\footnotetext{
${ }^{33}$ In total there are 118 cities with subscriptions listed in Darnton (1973); 12 of these are not reported in Bairoch et al. (1988), and the remaining 21 can be matched to Bairoch et al., but population data are not available for 1750 .

${ }^{34}$ Where evidence on individual subscribers survived, it suggests that the vast majority lived in the same city where the purchase was recorded, or in towns or villages nearby that were too small to enter the Bairoch et al. data and thus do not confound our results. Appendix C.2 provides further discussion.

${ }^{35}$ One reason for the relatively low sales of the Quarto edition in Paris may have been the disproportionate supply of more expensive earlier editions to the capital. Darnton (1973, p.1348) thus points out that subscriptions to the Quarto
} 
use log-subscriber density as our baseline variable: $\ln S u b D e n s=\ln \left(S u b s /\right.$ pop $\left._{1750}+1\right)$, where $\operatorname{pop}_{1750}$ is city population in $1750 .{ }^{36}$ Since all subscriptions to the Quarto were sold at the same price including shipment (Darnton, 1979, p.264), lnSubDens is arguably a comparable measure for the local demand for the Encyclopédie, and thus for upper-tail knowledge.

\subsection{Additional Indicators for Economic Development}

Following a rich literature in economic history, we use soldier height as a proxy for historical living standards (c.f. Steckel, 1983; Brinkman, Drukker, and Slot, 1988; Komlos and Baten, 1998). We use department-level conscript height from Aron, Dumont, and Le Roy Ladurie (1972) for the period 1819-1826 as our first proxy for living standards after French industrialization had begun. These data have the advantage that they are not affected by selection of recruits: starting with the first revolutionary wars, French conscripts were drawn by lottery from all the 20-year-olds in a given district. In addition, to proxy for cross-sectional income prior to the onset of industrialization, we use recruit height before 1750. These data are provided by Komlos (2005) at the department level, reflecting almost 30,000 individual recruitment records over the first half of the 18th century. These earlier data are potentially subject to selection bias into volunteer armies. While this bias renders time-series inferences from height data problematic, cross-sectional comparisons are generally more reliable (Mokyr and Ó Gráda, 1996). ${ }^{37}$ Consequently, we interpret the results with caution, exploiting only the variation in height across French regions, but not within regions over time. We also filter out cohort- and age-specific patterns in the earlier soldier height data as described in Appendix C.3.

We use a number of additional proxies for economic development in the mid-19th century: disposable income in 1864 from Delefortrie and Morice (1959), industrial output and employment from the Statistique Industrielle in 1861, as well as wages in industry and agriculture (measured in 1852) from Goreaux (1956). Finally, we perform a detailed within-sector analysis, using local wages as a proxy for productivity. The underlying data are from Chanut, Heffer, Mairesse, and

\footnotetext{
"should not be taken to prove that the capital of the Enlightenment absorbed relatively few Encyclopédies. What it provides is a fairly accurate picture of Encyclopédie diffusion in the provinces." We address this issue by including a dummy for Paris in all our regressions.

${ }^{36}$ Adding a positive number ensures that the measure is also defined for cities with zero subscriptions, and more precisely, adding the number 1 yields $\ln S u b D e n s=0$ in these cases. This reflects a normalization, so that in cities with $S u b s=0$, there is no relationship between subscriptions and growth. The simpler specification without logs $\left(\right.$ SubDens $=S u b s /$ pop $\left._{1750}\right)$ has the same property, but is more prone to outliers; we show in the Online Appendix that all our results are robust to using SubDens. In addition, we use a dummy for above-zero subscriptions $\left(I_{S u b s}>0\right)$ to differentiate between extensive and intensive margin effects. Appendix C.2 provides further detail and distribution plots for the alternative measures.

${ }^{37}$ Cross-sectional analyses typically document a strong positive correlation between height and per capita income (see Steckel, 2008, for a recent survey of the literature and empirical evidence). In longitudinal studies, the relationship may also be confounded by income inequality, volatility, or food prices (Komlos, 1998).
} 
Postel-Vinay (2000), who cleaned and digitized a survey of 14,238 firms from 1839-1847. The data, collected by the Statistique Générale de la France at the arrondissement (sub-county) level, categorize firms into 16 industrial sectors.

\subsection{Literacy and Control Variables}

In the following, we briefly describe our set of control variables, including those for worker skills. Appendix C.4 provides more detailed descriptions and sources, and Table E.2 at the end of the Appendix lists all variables together with a brief description. Literacy rates at the French department level are available in 1686 and 1786 from Furet and Ozouf (1977), reflecting the percentage of men able to sign their wedding certificate. For later periods, department-level schooling data are available from Murphy (2010), computed as the ratio of students to school-age population (5 to 15 years) in 1837. Following the discussion in Section 2.4, we use these rates to proxy for the share of skilled workers at different points in time in our sample.

Our baseline set of controls includes various geographic characteristics of cities, such as dummies for ports on the Atlantic Ocean and on the Mediterranean Sea, as well as for cities located on navigable rivers. Following Dittmar (2011), we also include a dummy for cities that had a university before 1750, a printing press between 1450 and 1500, and the log number of editions printed before 1501. To control for cultural and language differences, we construct a dummy for cities located in non-French speaking departments. ${ }^{38}$

We also control for a number of potential confounding factors. These include total book sales at the French city level over the period 1769-1794 from the Swiss publishing house STN (which also published the Encyclopédie). We match more than 140,000 sold copies to the cities in our dataset. We obtain the number of noble families in each department from the Almanach de Saxe Gotha, the most important classification of European royalty and nobility. Altogether, our sample contains more than 1,000 noble families in 1750, in 88 French departments. We also control for early industrial activity in France, following Abramson and Boix (2013). These data provide the number of mines, forges, iron trading locations, and textile manufactures prior to 1500 for each department. In addition, we compute each city's distance from the nearest coal field mined in the 19th century, based on data from Barraclough (1978). Finally, to proxy for the reach of centralized institutions, we include a dummy for cities located in pays d'élection, where the king exerted particularly strong power in fiscal and financial matters (Mousnier, 1979).

In order to guarantee consistency with our main explanatory variable (lnSubDens), we calculate the local density of total book sales, noble families in 1750 , and pre-industrial locations in the

\footnotetext{
${ }^{38}$ There were a number of regions in 18C France that spoke different languages, such as Alsacien and Basque. The corresponding six departments comprise 24 cities in our sample, out of which six had above-zero subscriptions.
} 
same way as for subscriptions: $\ln \left(1+x / p o p_{n, 1750}\right)$. Appendix C.5 describes how we aggregate city-level variables to the arrondissement and department level.

\subsection{Balancedness}

Do other town characteristics vary systematically with Encyclopédie subscriptions? In Table 1 we regress our main explanatory variable $\ln S u b D e n s$ on a variety of controls (one by one). We begin with our baseline controls in panel A. Column 1 uses all cities, while column 2 uses only those with above-zero subscriptions. Few control variables show a consistent pattern. City size is significantly positively correlated with $\ln S u b D e n s$ in column 1 , but significantly negatively in column $2 .{ }^{39}$ Seaports are essentially uncorrelated with subscriber density. The coefficient on navigable rivers is significant in column 1 but switches signs and becomes insignificant in column 2. Cities in non-French speaking areas (such as the Basque region) have a smaller proportion of subscribers. Panel B examines early knowledge controls. The correlation of $\ln S u b$ Dens with university and printing press dummies, as well as with books printed before 1500, are all positive (and significant in column 1), as one should expect, since they also reflect local access to knowledge.

Next, columns 3-5 in Table 1 regress subscriber density on our proxies for average worker skills (panel C), as well as a variety of potentially confounding variables (panel D). ${ }^{40}$ Literacy rates in both 1686 and 1786, as well as schooling rates in 1837, are not significantly correlated with subscriber density in any specification. On the other hand, overall (STN) book purchases are strongly and positively associated with Encyclopédie subscriptions. This suggests that locations with a greater interest in reading also hosted more people with scientific interests. Next, there is no systematic relationship between subscriber density and the reach of centralized institutions as reflected by pay d'élection. The correlation between $\ln S u b D e n s$ and pre-industrial activity is small, negative, and insignificant; the same is true for distance to coal fields once we include our baseline controls (column 4), and the relationship switches signs when restricting the sample to cities with above-zero subscriptions (column 5). This makes it unlikely that our results are confounded by early industrial centers or the availability of coal (Fernihough and O'Rourke, 2014). Finally, the local density of noble families is positively associated with subscriber density, with a significant coefficient in column 5. Appendix C.6 provides further tests of balancedness, comparing cities with and without subscriptions, as well as those with above- and below-median subscriber density.

\footnotetext{
${ }^{39}$ Below, we confirm that our results hold in both samples. Note that this implicitly addresses potential unobserved factors that are associated with both city size and $\ln S u b D e n s$, because the correlation with city size changes signs between the two samples.

${ }^{40}$ Column 3 reports coefficients without controls, column 4 adds controls, and column 5 restricts the sample to cities and departments with above-zero subscriptions. For those variables that are observed at the department level, we aggregate city-level subscriber density to departments (see Appendix C.5). The department-level data comprise 88 observations in the cross-section, and the vast majority of these had above-zero subscriptions.
} 
These additional tests confirm the pattern described above: the few city characteristics that vary systematically with subscriber density are those that one should expect if subscriptions reflect the size of the local knowledge elite.

\section{Main Empirical Results}

In this section we present our empirical results. We estimate equations of the form

$$
y_{n}=\beta \cdot S_{n}+\gamma \cdot h_{n}+\delta \mathbf{X}_{n}+\varepsilon_{n},
$$

where $S_{n}$ represents our proxies for knowledge elites in location $n$ (with subscriber density as our baseline measure); $h_{n}$ denotes proxies for average human capital, such as literacy and schooling; $\mathbf{X}_{\mathbf{n}}$ is a vector of control variables, and $\varepsilon_{n}$ represents the error term. We use a variety of outcome variables $y_{n}$. Following our discussion in Section 2 (formalized in the model in Appendix A), we expect knowledge elites to foster the adoption of new technology and therefore growth - especially when the technological frontier expands quickly. On the other hand, average human capital may affect the productivity of any given mode of production (and thus income levels), but not the adoption of new technology (and thus not growth). When the dependent variable in (1) is city growth, we therefore expect $\gamma=0$, as well as $\beta>0$ in periods of rapid technological progress, i.e., after 1750. When $y_{n}$ reflects level variables such as income proxies, we expect $\gamma>0$ for both the pre-industrial and modern periods, and $\beta>0$ in the 19th century, i.e., after industrialization has been under way sufficiently long for the growth relationship with $S_{n}$ to affect outcome levels.

\subsection{City Growth}

Because detailed regional income data are not available for early modern Europe, city population is a widely used proxy for economic development (DeLong and Shleifer, 1993; Acemoglu, Johnson, and Robinson, 2005; Dittmar, 2011). While cities needed a productive countryside to ensure food supply, industrial and mercantile activities within their boundaries were crucial for attracting migration, the prime driver of city growth in early modern Europe. In addition, one "can use the sizes of European cities as indicators of commercial prosperity because the typical post-Classical European city was primarily a center of commerce, and not of bureaucracy, administration, or landlord consumption" (DeLong and Shleifer, 1993, p.675). The strong relationship between income and city growth holds not only in the pre-industrial context, but also in modern data (c.f. Glaeser, Scheinkman, and Shleifer, 1995). Following this approach, our main outcome variable is gpop $_{n t}$, the log growth of city population between periods $t-1$ and $t$ (100- or 50-year intervals). Figure 3 shows the distribution of gpop $_{n t}$ for different subscriber densities over the period 17501850. During industrialization in France, cities with Encyclopédie subscriptions grew substantially 
faster: the city growth distribution is markedly shifted to the right. In addition, this shift is more pronounced for cities with above-median subscriptions per capita. In the following, we analyze this pattern more systematically.

\section{Cities with vs. without subscriptions: matching estimation}

Between 1750 and 1850, cities with above-zero subscriptions to the Encyclopédie grew at approximately double the rate as compared to those without subscribers (0.51 vs. $0.26 \log$ points). However, merely comparing the two subsets is problematic, because larger cities are more likely to have at least one subscriber. As a first pass at this issue, we match on population, comparing cities with and without subscriptions of similar size. This yields a very similar growth difference: 0.51 vs. $0.28 \log$ points (see Figure D.1 in the Appendix). We then use propensity score matching in a variety of specifications reported in Table $2 .{ }^{41}$ Columns 1-4 show results for a variety of specifications for the period 1750-1850. In column 1, we use the full sample and match by initial population; column 2 excludes the $10 \%$ smallest and largest cities in 1750 . In columns 3 and 4, we introduce geographic latitude and longitude as additional matching variables. ${ }^{42}$ We thus compare nearby cities with similar population size, accounting for unobserved heterogeneity at the local level. The results are stable and economically significant throughout: French cities with subscriptions grew approximately $0.15-0.25 \log$ points faster (relative to an average city growth rate of 0.37 $\log$ points) than those of comparable size without subscriptions. In columns 5 and 6, we repeat the analysis for the period 1700-50. The difference in growth is now substantially smaller and statistically insignificant. The matching results thus suggest that the relationship between knowledge elites and growth gained strength after the onset of industrialization in the mid-18th century. ${ }^{43}$

\section{Subscriber density and city growth}

We now turn to our main explanatory variable, subscriber density $\ln S u b D e n s$, using OLS regressions. This offers several advantages over the previous matching exercise: it exploits the full variation in subscriber density (instead of only a dummy); we can examine the coefficient on controls to see how they affect city growth; and we can use population-based weights to reduce the

\footnotetext{
${ }^{41}$ Following Abadie, Drukker, Herr, and Imbens (2004), we use the three nearest neighbors. Our results are robust to alternative numbers of neighbors. We define "treatment" as cities with above-zero subscriptions and report average treatment of the treated (ATT) effects. We exclude the top and bottom 1-percentile of city growth rates for each respective period. This avoids that extreme outliers due to population changes of very small towns (for example, from 1,000 to 4,000 or vice versa) affect our results. In the OLS analysis below, we address this issue by using population weights; in propensity score matching, weighting by city size is not feasible.

${ }^{42}$ The average population difference between matched cities with and without subscriptions is 6,500 inhabitants in column 1 , and 500 inhabitants in column 2 . When matching by geographic location (column 3 ), matched cities are on average less than 30 miles apart.

${ }^{43} \mathrm{~A}$ simple t-test shows that the difference of coefficients in columns 5 and 6 is statistically significant at the 10 percent level; we provide more detailed tests along these lines in the panel analysis below.
} 
noise in growth rates due to population changes in small cities - there is more reliable information in a city growing from 100,000 to 200,000 inhabitants than in one growing from 1,000 to 2,000.

Table 3 presents our main OLS results for city growth. Column 1 controls only for initial population, showing that subscriber density is strongly positively associated with city growth over the period 1750-1850. Column 2 adds more controls: Atlantic and Mediterranean ports also grew significantly faster; the former is in line with Acemoglu et al. (2005). The negative coefficient on initial population (after controlling for other characteristics) provides some evidence for conditional convergence (Barro and Sala-i-Martin, 1992). Both Paris and cities in non-French speaking areas grew faster than average between 1750 and $1850 .{ }^{44}$ Column 3 adds our early knowledge controls: a university dummy and an indicator for cities that had a printing press in 1500, as well as the log number of editions printed by that date. This replicates the specification in Dittmar (2011), who shows that early adoption of printing had a strong positive effect on city growth in Europe overall after 1500, long before industrialization. Within France, and during the later period of our analysis, this pattern is not present. Importantly, the coefficient on $\ln S u b D e n s$ remains strongly significant as we successively add controls. To gauge the corresponding magnitude, the bottom of Table 3 shows that cities with subscriber density in the 75th percentile (conditional on $S u b s>0$ ) grew approximately $0.3 \log$ points faster than those without subscribers (relative to a mean growth of $0.37 \log$ points with a standard deviation of 0.49 ). We also report standardized beta coefficients, showing that a one standard deviation increase in subscriber density is associated with an increase in city growth by about 0.3 standard deviations.

In column 4, we include a dummy for cities with at least one subscriber. This helps us to disentangle the extensive and intensive margin, i.e., whether our results are driven by the difference between cities with any subscribers vs. none, or whether having a higher subscriber density matters in itself. For example, if a single enlightened individual was sufficient to spread uppertail knowledge throughout a city - no matter how large the population - then only the extensive margin would matter. On the other hand, if upper-tail knowledge did not spread easily beyond the elite (for example, due to a general lack of advanced the other hand, if upper-tail knowledge did not spread easily beyond the elite (for example, due to a general lack of advanced provide limited support for the extensive margin, and strong support for the intensive one: The dummy $I_{S u b s>0}$ is positive but insignificant, while the coefficient on subscriber density is almost unchanged (as compared to column 3) and remains highly significant. The bottom row in the table helps to illustrate the magnitude of the two margins: moving from cities without subscribers to the 75 th percentile

\footnotetext{
${ }^{44}$ The latter is mostly due to six Alsatian-speaking cities in the Rhine area, which saw rapid growth during industrialization. When including a separate Rhine-area dummy, the coefficient of non-French speaking falls to less than one-half its original size, while the coefficient on $\ln S u b D e n s$ is unchanged.
} 
of those with subscribers raises growth by $0.384 \log$ points, and only 0.13 of this is due to the extensive margin. Consequently, the density of knowledge elites played a crucial role. This is confirmed when we exploit only the intensive margin, restricting the sample to cities with above-zero subscriptions (column 5). Our results are also robust when not weighted by initial city population (column 6), and when we use subscriber density without logs (column 7).

Finally, column 8 repeats the analysis for 1700-50, the closest period before France began to industrialize. For now, we use our main explanatory variable $\ln S u b D e n s$ also as a proxy for pre1750 knowledge elites. This reflects our argument that the spatial distribution of scientific elites was relatively stable over time, which is supported by the evidence in Section 5.1 below. The coefficient on $\ln S u b D e n s$ is now small and insignificant; also, the difference between the postand pre-1750 coefficients is strongly significant: the $95 \%$ confidence intervals of the estimate for $\ln S u b$ Dens in columns 3 and 8 do not overlap. In the following, we provide further support for a strengthening in the relationship between upper-tail knowledge and growth after the onset of industrialization.

\section{Subscriber density: Panel estimation}

Table 4 exploits the panel dimension of our city population data, replicating the specification from Nunn and Qian (2011). This specification includes city fixed effects, absorbing all unobserved characteristics that do not vary over time. We find that the interaction of $\ln S u b D e n s$ with a post1750 dummy is highly significant and positive, with a magnitude that is very similar to the growth regressions above. This finding is robust to including interactions of the post-1750 dummy with our baseline controls (column 2), as well as with our additional controls (column 3). The baseline result also holds in the balanced samples in columns 4 and 5, which include only the 45 (148) French cities where population is observed in every sample year between 1500 and 1850 (1700 and 1850). ${ }^{45}$ Finally, columns 6 and 7 report the results for placebo cutoffs in 1600 and 1700. Both yield small, negative, and insignificant coefficients (that differ from the coefficient of the 1750 cutoff, with p-values 0.03 and 0.003 , respectively). Our results thus suggest that the local relationship between knowledge elites and growth became stronger when aggregate technological progress accelerated. ${ }^{46}$

\footnotetext{
${ }^{45}$ The results in column 5 are particularly useful for addressing the concern that cities with high subscriber density in the mid-18th century may already have been richer and on a different growth path: any initial income differences in 1700 are absorbed by city fixed effects. In addition, there is no association between subscriber density and city growth in 1700-50 (column 8 in Table 3). Thus, it is unlikely that (after controlling for city fixed effects) unobserved income in 1750 is correlated with $\ln S u b D e n s$ and confounds the results in column 5.

${ }^{46}$ Note that this does not imply that advanced knowledge was unimportant prior to 1750 . As discussed above, (non-technical) upper-tail knowledge could play an important role in periods of economic expansion prior to industrialization - for example, advanced legal and commercial knowledge during the "Commercial Revolution," a period that also witnessed a proliferation of cities (Cantoni and Yuchtman, 2014; Dittmar, 2013).
} 


\section{Literacy and additional controls}

Table 5 examines the relationship between average worker skills (with literacy as a proxy, following the discussion in Section 2.4) and city growth. ${ }^{47}$ We also add our additional control variables in columns 2-4. The coefficient on literacy is small and negative throughout, and marginally significant in one specification. This is in line with the well-documented declining importance of worker skills during the onset of industrialization. ${ }^{48}$ Column 2 uses an additional proxy for human capital: overall city-level book sales by STN (the publisher of the Encyclopédie). While these are strongly correlated with $\ln S u b$ Dens (see Table 1), they do not affect city growth. This provides important support for our argument that upper-tail knowledge, but not the level of general literacy, affected growth. In addition, the non-finding for overall book sales also serves as a "placebo," making it unlikely that our results are driven by book consumption rising with income, i.e., affluent individuals stocking their libraries.

Among the remaining controls in Table 5, only pre-industrial activity is positively and significantly associated with city growth (column 3). Distance to coal, the reach of central institutions (pays d'élection), and nobility density have small and insignificant coefficients. In Appendix D.1 we show that this also holds when including controls one by one (Table D.7), and we discuss the individual coefficients in detail. Finally, column 4 adds an indicator for cities with above-zero subscriptions, confirming the pattern from column 4 in Table 3: a positive but insignificant extensive margin, and a strong intensive margin of subscriber density. Importantly, in all regressions the coefficient on $\ln S u b D e n s$ remains very similar and highly significant. In sum, the results in Table 5 strongly support our argument that there was a crucial difference between average worker skills and upper-tail knowledge during industrialization.

\section{Robustness: Alternative specifications and samples}

We perform a number of robustness checks in Appendix D.1, where we provide additional tables and discussions. Here, we sketch the main robustness results. We begin by splitting our main sample period, 1750-1850. The French Revolution occurred approximately in the middle of this period, followed by a radical change in institutions. In Table D. 1 we show that our results hold for both sub-periods, 1750-1800 and 1800-1850, i.e., cities with higher subscriber density grew faster under both political regimes. This makes it unlikely that subscriber density reflects unobserved institutions that in turn drive growth, complementing our results for pays d'élection. We then run our city growth regressions for the period 1750-1850, using four different subsamples, each

\footnotetext{
${ }^{47}$ Standard errors are now clustered at the department level, the geographical unit at which literacy is observed.

${ }^{48}$ For example, Goldin and Katz (1998) argue that the shift from artisan workshops to factories replaced craftsman skills with unskilled labor. This is supported by the evidence in de Pleijt and Weisdorf (2014) who document a significant shift toward unskilled workers during the first Industrial Revolution in England.
} 
including those cities for which population data are available in the years 1400,1500, 1600, and 1700 , respectively. The coefficients on $\ln S u b$ Dens are very similar to our baseline results and are always significant at the $1 \%$ level (Table D.2). The same is true when we split our sample by terciles of city size in 1750 (Table D.3): our results are equally strong for small, medium, and large cities. In Table D.4, we use a specification that does not impose a linear relationship between $\ln S u b D e n s$ and city growth; instead, we include three indicator variables for increasing subscriber density. We find that the coefficients increase for each step and that the differences are statistically significant, providing further support for the importance of the intensive margin. In Tables D.5 and D.6, we check the robustness of our results to restricting the sample to cities with positive subscriptions, and to alternative definitions of subscriber density. In addition to the standard measure $\ln S u b D e n s$, we use two alternatives: one that is not log-based, and another one that allows for variation in subscriber density across cities without subscriptions, assigning lower densities to larger cities. All our results continue to hold. Finally, we provide further results on the role of literacy in Tables D.8 and D.9.

\subsection{Other Outcome Variables}

We now turn to cross-sectional results, analyzing a variety of outcome variables at the department level.

\section{Soldier height}

We begin by using a common proxy for income, soldier height. This variable is available for French departments before and after 1750, allowing us to examine the cross-sectional relationship between income and human capital (for both knowledge elites and worker skills) before and after the onset of industrialization. Columns 1 and 2 in Table 6 show that conscript height in 1819-26 is strongly positively associated with both subscriber density and literacy. Columns 3 and 4 show that soldier height prior to 1750 is also positively associated with literacy, but not with $\ln S u b$ Dens. ${ }^{49}$ These results are in line with our discussion above (and with the model in Appendix A): while worker skills raise the productivity level in any given (pre-industrial or modern) technology, upper-tail knowledge fosters industrial growth and therefore shows a stronger relationship with development after industrialization has been on its way for some time. Finally, in columns 5 and 6, we show that changes in literacy and initial levels of subscriber density are strongly associated with 1819-26 soldier height, after controlling for pre-1750 soldier height as a (rough) proxy

\footnotetext{
${ }^{49}$ While noise in the early height data is an obvious concern, the significant correlation with early literacy is comforting. Table D.10 in the Appendix reports further robustness checks, showing that all results hold when regressing conscript height separately on $\ln$ SubDens and Literacy, and when weighting regressions by the number of soldiers for which pre-1750 height is observed in each department.
} 
for initial development. These results have to be interpreted with caution because soldier height from the two periods is not directly comparable due to possible selection into pre-1750 volunteer armies (see Section 3.2). Also, reverse causation is a potential problem when interpreting the coefficient on literacy - economic growth may have led to higher literacy, rather than the other way around. If taken at face value, the corresponding point estimates imply that a one standard deviation increase in $\ln S u b$ Dens (change in literacy) is associated with soldier height being higher by $0.3 \mathrm{~cm}(0.4 \mathrm{~cm})$, relative to a standard deviation in soldier height of $1.3 \mathrm{~cm}$ across departments, and an average height of $166 \mathrm{~cm} .{ }^{50}$

\section{Disposable income, industrial activity, and wages}

In column 1 of Table 7, we show that Encyclopédie subscriptions in the mid-18th century predict disposable income in 1864 , i.e., about a century later. The point estimate implies that a one standard-deviation increase in $\ln S u b$ Dens is associated with 5.2 percent (0.24 standard deviations) higher income. The standardized effect is very similar to the one observed for soldier height, where the beta coefficient is 0.23 . In columns 2 and 3, we use industrial output and industrial employment per capita in 1861 as dependent variables. These show a very similar pattern as disposable income. Next, we use department-level wages from 1852. Subscriber density is a positive and significant predictor of industrial wages (column 4), but is not significantly associated with wages in agriculture (column 5). The latter is in line with historical evidence that increasing food production initially depended more on the "intensive use of known technology than on novel methods" (Grantham, 1989, p.44) and that scientific knowledge was not important in agriculture before the mid-19th century (Johnson, 1997, see Appendix E.2 for further discussion). Finally, as a proxy for average worker skills, we can now use department-level schooling rates, which are available for 1837. This variable is positively and significantly associated with income levels, industrial activity, and with wages in both sectors.

\section{Mechanisms and Interpretation}

In this section, we shed light on the mechanisms that may drive the strong relationship between Encyclopédie subscriber density and economic development during industrialization. We begin by using alternative proxies to show that locations with higher subscriber density were host to a stronger interest in "useful knowledge" and more scientific activity both before and after the mid18 th century. In addition, we discuss one possible historical root of the observed spatial pattern the presence of Huguenot minorities. We then provide evidence for a central role of knowledge

\footnotetext{
${ }^{50}$ The standardized beta coefficient of literacy in 1686 is almost identical for pre-1750 soldier height and height in 1819-26 (even if we do not control for pre-1750 height in the latter regression). This suggests that initial literacy levels did not contribute to differential growth.
} 
elites in the adoption of new technology, showing that locations with high subscriber density had more productive firms almost a century later, and that this effect was particularly strong in sectors that experienced rapid innovation.

\subsection{Local Persistence and Alternative Proxies for Upper-Tail Knowledge}

We argue that Encyclopédie subscriber density reflects the presence of scientific elites. In the following, we provide evidence that this pattern was locally stable.

\section{Scientific societies}

Scientific societies are a prime example for the emergence of scientific activity during the Age of Enlightenment (Mokyr, 2005b). In France, there were 22 cities with scientific societies founded before 1750 (see Appendix D.3 for detail). These cities were over three times more likely to be home to Encyclopédie subscribers, and they had almost four times more subscribers per capita than cities without scientific societies (Table D.11 in the Appendix). In other words, subscriber density was high where scientific elites were present before 1750 .

The data on pre-1750 scientific societies also allow us to address the possibility of reverse causality: since the Quarto edition was printed in 1777-79, initial industrial growth between 175080 may have raised the demand for the Encyclopédie. In columns 1-3 of Table 8, we repeat our city growth regressions, using scientific societies as the explanatory variable. Both propensity score matching (panel A) and OLS estimation using member density (panel B) confirm our main results: cities with pre-1750 scientific societies grew significantly faster during French industrialization; the intensive margin of members per capita is important (column 2 in panel B); and the relationship before 1750 is substantially smaller (column 3 ). ${ }^{51}$

\section{Descriptions des Arts et Métiers}

The Encyclopédie was not the only knowledge collection published in the spirit of enlightenment in Ancien Régime France. Another example is the massive multi-volume Descriptions des Arts et Métiers, which was entirely devoted to the "useful arts" of the time, with a particular emphasis on manufacturing knowledge and industrial activities such as textiles and iron production (for further detail and sources, see Appendix D.3). There is a strong positive relationship between sales of the Descriptions des Arts et Métiers and Encyclopédie subscriptions, which we document in Tables D.12 and D.13 in the Appendix.

Sales of the Descriptions des Arts et Métiers are also strongly associated with city growth during French industrialization, as shown in columns 4 and 5 of Table 8. Note also from panel B,

\footnotetext{
${ }^{51}$ Local density of scientific society members (lnMembDens) in panel $\mathrm{B}$ is calculated in the same way as lnSubDens (see Section 3.1). The two measures are strongly correlated, with a coefficient of 0.313 (p-value 0.0001 ).
} 
column 5 that the intensive margin of sales dominates the extensive one. In other words, similar to our finding for Encyclopédie subscriptions, more sales mattered.

People in scientific professions

Next, we present two additional variables that also point toward a persistent spatial distribution of scientific elites. First, we use data on "famous" people in 1000-1887 from the Index BioBibliographicus Notorum Hominum (IBN), as coded by de la Croix and Licandro (2012). We identify 2,513 individuals who worked in scientific professions (science, mathematics, chemistry, physics, or medicine) and who can be matched to our sample by city of birth and/or city of death. Columns 1-4 in Table 9 show a strong positive relationship between subscriber density and the local density of "famous scientists." 52 Results are similar for city of birth and city of death. In Appendix D.3 we also document a tight relationship between the number of famous scientists born and deceased in French cities - close to a $45^{\circ}$ line, with the exception of Paris, which systematically attracted scientists. Since Paris is captured by a dummy in all our regressions, it is unlikely that mobility of knowledge elites confounds our results. Second, columns 5 and 6 use department-level information on people in scientific professions from the 1851 Recensement, summing those related to medicine as well as hommes de lettres et savants. Again, their density is significantly higher in areas that had more Encyclopédie subscribers.

\section{Exhibitions of local innovations}

Columns 7 and 8 in Table 9 show that cities with higher subscriber density also presented significantly more innovations at the London world fair in 1851 (this holds even after controlling for the share of industrial employment in column 8). ${ }^{53}$ Altogether, a consistent pattern emerges where subscriber density reflects more scientific activity both before and after the time period when the Encyclopédie's Quarto edition was printed.

\subsection{Historical Roots: Huguenots and Upper-Tail Knowledge}

So far, we have taken the spatial dispersion of scientific elites - proxied by $\ln S u b D e n s$ - as given. Historians of science have documented this scattered pattern and pointed to a variety of local factors that attracted scientific activity in early modern Europe (Livingstone, 2003). However, these factors have not been analyzed systematically. In the following, we shed light on one historical root of advanced knowledge in France. The Huguenots - the protestant minority - represented an

\footnotetext{
${ }^{52}$ The dependent variable is defined as $\ln (1+$ famous scientists/pop 1750$)$; for city of birth in columns $1-2$, and city of death in columns 3-4. We divide by city population in 1750 because this is closest to the mean year of birth of the "famous" individuals.

${ }^{53}$ The dependent variable is based on 1,261 exhibits from France, coded by Moser (2005), which we matched to 78 cities in our dataset. We calculate the dependent variable as $\ln (1+$ number of exhibits/pop 1850$)$. See Appendix D.3 for further detail.
} 
important part of the entrepreneurial and knowledge elite (Scoville, 1953; Hornung, 2014). Contemporaneous observers around 1700 point out that Huguenots "were determined to acquire an education so they could read, write, and master arithmetic," and that they were "skillful in trade and daring in enterprise, apply themselves well to commerce and have all the genius which is needed to succeed in their profession" (cited after Scoville, 1953, pp. 429, 444). One explanation for this focus on entrepreneurship in combination with knowledge is the status of Huguenots as a "penalized minority." ${ }^{4}$ Employment opportunities for Huguenots were restricted, confining them to professions in the private industry, trade, and finance, where they had a comparative advantage due to the Protestant emphasis on education. ${ }^{55}$ In addition, while successful Catholic merchants and craftsmen would often seek pass into public office or into the nobility (via marriage), this path was closed to Huguenots. This reinforced their specialization on entrepreneurship and education. As a result, "there were a large number of individuals among them who were powerful and very intelligent in business affairs" (Scoville, 1953, p.442). Summarizing this argument, Scoville cites the Frenchman Beaumelle, who characterized Huguenots in the mid-18th century as "enlightened and capable of grasping all new ideas, and of borrowing new technical processes from abroad which will help them gain success" (ibid., p.444).

In Table 10, we examine the relationship between Huguenots, subscriber density, and city growth systematically. Column 1 shows that the Huguenot population share in 1670 is a strong predictor of subscriber density a century later, confirming the "special appeal of the Encyclopédie for Huguenots" documented by Darnton $\left(1979\right.$, p.284) ${ }^{56}$ Of course, this does not mean that the majority of Huguenots were highly educated. Instead, it indicates that they had a higher probability of ascending to the knowledge elite. ${ }^{57}$ On the other hand, Huguenot presence does not predict literacy (column 2). This is not astonishing: despite their individual education, the Huguenot share in the population overall was too small to systematically affect average literacy. ${ }^{58}$

\footnotetext{
${ }^{54}$ Huguenots were persecuted after they converted to Protestantism in the 16th century. The Edict of Nantes in 1598 temporarily granted religious freedom, but it was revoked in 1685, and Protestantism was declared illegal in France. As a result, about 10\% of the approximately 1.5-2 million Huguenots left France. Hornung (2014) shows that Huguenot migrants brought technological knowhow to their destinations, raising the productivity of local firms.

${ }^{55}$ The latter part of this argument is similar to Botticini and Eckstein (2012), i.e., that the Jewish religion's emphasis on education provided a comparative advantage in commerce and trade, resulting in the choice of prosperous urban professions (even in the absence of occupational discrimination).

${ }^{56}$ See Appendix D.4 for details on the Huguenot population share. We also show that the spatial distributions of Huguenots remained relatively stable between 1670 and 1815, i.e., that emigration after the revocation of the Edict of Nantes was not disproportionately stronger in some regions than in others.

${ }^{57}$ In fact, this is similar to the pattern that emerges for another highly educated minority today: while Jews account only for about 1 percent of the total European and U.S. population, they have an important impact in the scientific world, having received more than 20 percent of Nobel Prizes.

${ }^{58}$ In contrast, where Protestants account for the majority of the local population, their impact on literacy can be substantial (Becker and Woessmann, 2009).
} 
The remaining results in Table 10 show that areas with higher Huguenot density in 1670 witnessed significantly faster city growth after 1750 (column 3). Interestingly, this effect becomes small and insignificant once we control for subscriber density (column 4). This suggests that an important part of the relationship between Huguenot presence and city growth worked via upper-tail knowledge, while effects of religion (such as a Protestant work ethic) were probably less crucial. In other words, it is unlikely that Huguenots purchased the Encyclopédie for religious reasons; a more plausible interpretation is that they formed part of the knowledge elite who became important for growth during industrialization. ${ }^{59}$ Finally, in line with our argument, the association between Huguenot presence and growth only emerged after 1750 (columns 5 and 6).

\subsection{Innovation, Knowledge Elites, and Productivity}

If upper-tail knowledge helped entrepreneurs to keep up with technological progress, the effect of knowledge elites on local productivity should be particularly strong in sectors that saw rapid innovation. To test this, we implement a two-step argument. We first show that Encyclopédie subscriptions predominantly reflect modern technology: the majority of technologies that it described and illustrated were innovative. Second, we show that subscriber density predicts firm productivity in modern (innovative), but not in traditional, manufacturing sectors.

\section{From English patents to plates in the Encyclopédie}

Nuvolari and Tartari (2011) provide data on the share of "inventive output" of 21 British industrial sectors for the period 1617-1841. This measure is based on reference-weighted patents, adjusted for the sector-specific frequency of patenting rates and citations. For example, textiles have the highest score, accounting for $16.6 \%$ of total inventive output; pottery, bricks, and stones are at the lower end, with a share of $1.4 \%$. As a first step, we use the British patent data to analyze whether modern, innovative sectors were prominently represented in the Encyclopédie. We obtain detailed information on 2,575 plates that the Encyclopédie used to illustrate crafts, processes, and inventions (see Appendix D.5 for sources and further detail). About half of these describe manufacturing technologies, and they include examples such as "cloth cutting and figuring" or "machines to evacuate water from a mine." We match plates to the 21 British industrial sectors, which allows us to split them into "modern" and "old" technologies, corresponding to above- and below-median share of total inventive output. We find that more than two thirds of all plates dedicated to manufacturing in the Encyclopédie described modern technologies (see Table D.17 in the Appendix). This suggests that the knowledge elite subscribing to the Encyclopédie was interested

\footnotetext{
${ }^{59}$ Note that part of the observed pattern may also reflect access to financial means: Huguenots were not only more educated but also often affluent entrepreneurs. This is compatible with our interpretation that upper-tail knowledge was (at least) a proximate driver of industrialization, and investment in physical capital a complementary factor.
} 
in modern innovative, rather than traditional, technology.

\section{Knowledge elites and productivity in modern vs. traditional manufacturing}

We now analyze the relationship between subscriber density and firm productivity (with wages as a proxy for the latter) in modern versus old manufacturing sectors. This analysis builds on data from a French industrial survey of more than 14,000 firms in 1839-47, which reports the sector and firm location by arrondissement. ${ }^{60}$ We run the following regression:

$$
\ln \left(\text { wage }_{j n}\right)=\beta_{1} S_{n}+\beta_{2} S_{n} \times I_{j}^{M}+\gamma_{1} h_{n}+\gamma_{2} h_{n} \times I_{j}^{M}+\delta_{1} \mathbf{X}_{n}+\delta_{2} \mathbf{X}_{n} \times I_{j}^{M}+\alpha_{j}+\alpha_{n}+\varepsilon_{j n}
$$

where $w_{a g e}$ is the average male wage paid by firms operating in sector $j$ in arrondissement $n$. Our main explanatory variables are subscriber density $S_{n}$ and schooling rates $h_{n}$. $I_{j}^{M}$ is an indicator variable that takes on value one if sector $j$ is "modern." The vector $\mathbf{X}_{n}$ includes the controls used above, as well as total population and the urbanization rate in order to control for agglomeration effects. In addition, we control for sector fixed effects $\left(\alpha_{j}\right)$, location fixed effects $\left(\alpha_{n}\right)$, and for average firm size $\left(s i z e_{j n}\right)$ to capture scale effects.

If upper-tail knowledge affected development by raising the productivity in innovative technologies, we expect $\beta_{2}>0$, reflecting a stronger association between subscriber density and wages in modern as compared to old sectors. Table 11 presents compelling evidence in support of this hypothesis: $\beta_{2}$ is strongly positive. This holds after adding sector fixed effects (column 2), baseline and additional controls (columns 3 and 4), and also when including department or arrondissement fixed effects (columns 5 and 6). The base effect for old sectors (reflected by $\beta_{1}$ ), is smaller and less robust. The point estimates can be interpreted as follows: suppose that we "move" two representative firms - one in a modern sector and the other in an old sector - from an arrondissement without subscriptions to one in the 90th percentile of subscriber density (with $\ln S u b D e n s \approx 2$ ). Then productivity of the old firm would increase by $2-8$ percent. $^{61}$ For the modern firm, productivity would increase by an additional 10-14 percent, on top of the base effect captured by $\beta_{1}$. Turning to average worker skills (proxied by schooling) we find a strong base effect $\left(\gamma_{1}\right)$, but no additional effect in modern sectors. This is in line with our discussion above that worker skills raise productivity in a given technology, but do not lead to growth via adoption or innovation. With respect to firm size, larger establishments are more productive in old industries, but the net effect is essentially zero in modern industries. This suggests that scale effects (and thus investment constraints) are probably not a major confounding factor for our results. Finally, on

\footnotetext{
${ }^{60}$ French arrondissements correspond to the sub-county level - there were altogether 356 arrondissements in 86 departments in the mid-19th century. Appendix D.5 describes the firm survey in more detail and shows how we match French to British sectors. It also lists the resulting consistent eight sectors and their share of "inventive output."

${ }^{61}$ This suggests that upper-tail knowledge probably had some positive effects also in old sectors, where innovation was below the median, but above zero.
} 
average, modern sectors paid higher wages (column 1), as should be expected if they tend to use more productive technology.

In Table 12, we analyze the relationship between Encyclopédie subscriptions and wages within individual sectors. We rank sectors by the size of the coefficient on $\ln S u b D e n s$. The top four sectors are all "modern," and the bottom four are all "old." In particular, the coefficient on subscriber density is large within sectors that saw rapid innovation during industrialization, such as textiles or transportation (the first steamboat was built in France in 1783). For the least innovative sectors (leather; mining; ceramics and glass), subscriber density is only weakly related to wages. ${ }^{62}$ Table 12 also revisits the concern that unobserved local wealth may drive our results, i.e., that the rich could afford the Encyclopédie and also had the financial means to invest in industrial machines. We use two proxies for an industry's dependence on up-front investment: the number of steam engines (column 4), and the number of other engines such as wind and water mills (column 5). Interestingly, both measures for up-front investment tend to be higher in sectors where the effect of Encyclopédie subscriptions is weaker (such as metal and leather). This makes financial abundance less likely as a confounding factor. ${ }^{63}$ In sum, our analysis suggests that knowledge elites supported industrialization by raising the local productivity in modern (innovative) technology.

\subsection{Discussion: Interpretation and Limitations of Results}

We have documented a striking pattern: Encyclopédie subscriptions are strongly associated with economic growth and income after 1750. Our interpretation is not that the Encyclopédie turned its readers into entrepreneurs, or that it caused local upper-tail knowledge. Instead, we use subscriber density as an indicator for the local presence of knowledge elites. The geographic pattern was likely persistent: we provided evidence that locations with higher subscriber density hosted more knowledge elites both before and after the mid-18th century. If scientific elites were present before industrialization, why would their effect on growth strengthen so much after 1750? The historical account suggests that advanced knowledge was particularly important during periods of economic expansion (as formalized in our model in Appendix A). One early example is the Commercial Revolution in medieval Europe (Dittmar, 2013; Cantoni and Yuchtman, 2014). However, the prime example is the Industrial Revolution, when the aggregate technological frontier began to advance rapidly, and when scientific knowledge became economically "useful" (Mokyr, 2005b). The mechanism is not confined to inventors or scientists actively improving technology, but it also

\footnotetext{
${ }^{62}$ Column 3 shows that the number of observations and the $\mathrm{R}^{2}$ are similar for modern and old sectors. Thus, overall fit or small samples do not drive the differences in coefficients.

${ }^{63}$ Verley (1985, p.103-104) observes that the metal industry was particularly capital intensive and often operated by the rich nobility, while textile production occurred at a smaller scale and required much less capital. Thus, our finding that subscriber density is particularly strongly associated with productivity in the textile industry supports our knowledge-based explanation.
} 
comprises lower access costs (e.g., via information networks in the knowledge elite) and higher efficiency at adopting complex modern techniques. Thus, our interpretation emphasizes a broad concept of upper-tail knowledge - but one that is clearly distinct from ordinary worker skills.

Our empirical analysis follows the common approach to regress growth rates on initial levels of human capital (Barro, 2001). It thus also shares the common limitation that skills are not assigned exogenously to different locations, which makes causal inference difficult. Correspondingly, we do not claim that upper-tail knowledge was necessarily a fundamental driver of industrial growth. However, our results suggest that it was at least a proximate determinant. For this interpretation to be valid, we need to discuss potential confounding factors that also fit the observed empirical pattern, but work via channels unrelated to upper-tail knowledge: such factors would have to be correlated with subscriber density, affect growth only after 1750, and do so particularly strongly in innovative modern sectors. We have discussed some alternative explanations that might fit this pattern - institutions, broader knowledge (overall book purchases), and access to finance (presence of noble families) - and concluded that these are unlikely to fully account for our results. Among these, access to finance is the most probable additional driver of industrial development. In modern economies, advanced education and income are strongly related; this was also true in the period that we analyze, where a substantial share of Encyclopédie subscribers came from the progressive bourgeoisie and nobility. Nevertheless, deep pockets alone are unlikely to explain industrial growth - even the most affluent individuals could not invest in technology they did not know about. In this sense, physical capital is not a "competing" factor, but rather another proximate driver that is complementary to upper-tail human capital. In sum, the historical evidence in combination with our empirical results make it hard to imagine that knowledge elites did not play an important role during industrialization.

We also showed that levels of literacy (reflecting average worker skills) were positively associated with development in the cross-section both before and after industrialization, but not with growth. For the cross-sectional results, reverse causality is a concern: income may have led to more literacy, rather than the other way around. Nevertheless, this can hardly explain our finding that initial literacy was not associated with growth during industrialization. Taken together, our empirical results strongly suggest that differentiating between average and upper-tail skills is crucial when analyzing the role of human capital for long-run development.

\section{Conclusion}

An ample literature has highlighted the importance of human capital for economic development in the modern world. However, its role during the Industrial Revolution has typically been described as minor. Hence, a crucial driver of modern growth appeared to be unrelated to the onset 
of growth itself, and thus to the greatest structural break in economic history. We resolved this puzzle by showing that not initial literacy of the masses, but upper-tail human capital - the presence of knowledge elites - played an important role during industrial growth. As a proxy for scientific elites, we use Encyclopédie subscriber density and show that this measure is strongly associated with other indicators of local scientific activity, both before and after the Encyclopédie was printed in the mid-18th century. We also shed light on one historical root of this spatial pattern - the presence of the suppressed Huguenot minority with its strong emphasis on educational attainment. A promising route for future research is to systematically examine the causes of the spatial dispersion of scientific elites at the eve of industrialization.

We discussed our empirical results in the context of a stylized framework of spatial knowledge diffusion, making two simple assumptions: while worker skills raise productivity for any given technology, upper-tail knowledge allows entrepreneurs to adopt more productive techniques. Thus, the former raise income per capita in the cross-section, while the latter fosters growth. In the spirit of Nelson and Phelps (1966), advanced knowledge is more important when the technological frontier expands rapidly. Consequently, upper-tail knowledge becomes particularly important for development during industrialization. Our data lend strong support to this prediction. Importantly, we do not argue that average worker skills were altogether unimportant; we show that they were strongly correlated with income levels before and after industrialization, but not with growth.

Our results have important implications for economic development: while improvements in basic schooling raise wages, greater worker skills alone are not sufficient for industrial takeoff. Instead, upper-tail skills - even if confined to a small elite - are crucial, fostering growth via the innovation and diffusion of modern technology. In this respect, our findings resemble those in today's economies, where the existence of a social class with high education is crucial for development (Acemoglu, Hassan, and Robinson, 2011), entrepreneurial skills matter beyond those of workers (Gennaioli et al., 2013), and scientific education is key (Hanushek and Kimko, 2000).

\section{References}

Abadie, A., D. Drukker, J. L. Herr, and G. W. Imbens (2004). Implementing Matching Estimators for Average Treatment Effects in Stata. Stata Journal 4, 290-311.

Abramson, S. F. and C. Boix (2013). The Roots of the Industrial Revolution: Political Institutions or (Socially Embedded) Know-How? APSA 2013 Annual Meeting Paper.

Acemoglu, D., P. Aghion, and F. Zilibotti (2006). Distance to Frontier, Selection, and Economic Growth. Journal of the European Economic Association 4(1), 37-74.

Acemoglu, D., F. A. Gallego, and J. A. Robinson (2014). Institutions, Human Capital and Development. Annual Review of Economics. forthcoming. 
Acemoglu, D., T. A. Hassan, and J. A. Robinson (2011). Social Structure and Development: A Legacy of the Holocaust in Russia. Quarterly Journal of Economics 126(2), 895-946.

Acemoglu, D., S. Johnson, and J. A. Robinson (2005). The Rise of Europe: Atlantic Trade, Institutional Change and Economic Growth. American Economic Review 95(3), 546-579.

Allen, R. C. (2003). Progress and Poverty in Early Modern Europe. Economic History Review 56(3), 403-443.

Allen, R. C. (2006). The High Wage Economy of Pre-industrial Britain. Nuffield working paper.

Antràs, P. and H.-J. Voth (2003). Factor Prices and Productivity Growth during the British Industrial Revolution. Explorations in Economic History 38, 52-77.

Aron, J. P., P. Dumont, and E. Le Roy Ladurie (1972). Anthropologie du Conscrit Français. Paris: Mouton De Gruyter.

Bairoch, P., J. Batou, and P. Chèvre (1988). La Population des villes Europeenees de 800 à 1850: Banque de Données et Analyse Sommaire des Résultats. Geneva: Centre d'histoire economique Internationale de l'Université de Genève, Libraire Droz.

Barbour, I. and S. Blydenburgh (1844). The Silk Culture in the United States. Greeley \& McElrath.

Barraclough, G. (1978). The Times Atlas of World History. London Times Books.

Barro, R. J. (1991). Economic Growth in a Cross Section of Countries. Quarterly Journal of Economics 106(2), 407-43.

Barro, R. J. (2001). Human Capital and Growth. American Economic Review Papers and Proceedings 91(2), $12-17$.

Barro, R. J. and X. Sala-i-Martin (1992). Convergence. Journal of Political Economy 100(2), 223-251.

Baten, J. and J. van Zanden (2008). Book Production and the Onset of Modern Economic Growth. Journal of Economic Growth 13(3), 217-235.

Becker, S. O., E. Hornung, and L. Woessmann (2011). Education and Catch-up in the Industrial Revolution. American Economic Journal: Macroeconomics 3(3), 92-126.

Becker, S. O. and L. Woessmann (2009). Was Weber Wrong? A Human Capital Theory of Protestant Economic History. Quarterly Journal of Economics 124(2), 531-596.

Benedict, P. (2005). Cities and Social Change in Early Modern France. London and New York: Routledge.

Benhabib, J. and M. M. Spiegel (1994). The Role of Human Capital in Economic Development: Evidence from Aggregate Cross-Country Data. Journal of Monetary Economics 34(2), 143-173.

Bils, M. and P. J. Klenow (2000). Does Schooling Cause Growth? American Economic Review 90(5), $1160-1183$.

Bloom, N. and J. Van Reenen (2007). Measuring and Explaining Management Practices Across Firms and Countries. Quarterly Journal of Economics 122(4), 1351-1408.

Botticini, M. and Z. Eckstein (2012). The Chosen Few: How Education Shaped Jewish History, 70-1492. Princeton University Press.

Braudel, F. (1982). Civilization and Capitalism, 15th-18th Century: The perspective of the world. University of California Press.

Brette, A. (1904). Atlas des bailliages ou jurisicatins asimilées ayant formé unité électorale en 1789 dressé 
d'après les actes de la convocation conservés au Archives nationales. Paris: Imprim. nationale.

Brinkman, H. J., J. Drukker, and B. Slot (1988). Height and Income: A New Method for the Estimation of Historical National Income Series. Explorations in Economic History 25(3), 227-264.

Broadberry, S. (2013). Accounting for the Great Divergence. Economic History Working Papers, 184/13. London School of Economics and Political Science, London, UK.

Cantoni, D. and N. Yuchtman (2014). Medieval Universities, Legal Institutions, and the Commercial Revolution. Quarterly Journal of Economics. forthcoming.

Carpenter, K. (2011). Physiocrats, Antiphysiocracy and Pfeiffer, Chapter Manufactures in European Economic Literature of the Enlightenment: The Description des Arts et Métiers and the Schauplatz der Künste und Handwerke, pp. 5-21. New York, Springer, 2011.

Carus-Wilson, E. M. (1966). The Woollen Industry. Cambridge Economic History of Europe. Volume II. Cambridge University Press.

Caselli, F. and W. J. Coleman (2006). The World Technology Frontier. American Economic Review 96(3), 499-522.

Chanut, J.-M., J. Heffer, J. Mairesse, and G. Postel-Vinay (2000). L'Industrie franccaise au milieu du 19e siécle: les enquêtes de la statistique générale de la France. Editions de l'école des hautes études en sciences sociales, Paris.

Chaptal, M. (1819). De l'Industrie Français, Volume 2. Paris.

Chaussinand-Nogaret, G. (1985). The French Nobility in the Eighteenth Century: From Feudalism to Enlightenment. Cambridge University Press.

Ciccone, A. and E. Papaioannou (2009). Human Capital, the Structure of Production, and Growth. Review of Economics and Statistics 91(1), 66-82.

Clair, C. (1976). A History of European Printing. London: Academic.

Clark, G. (1987). Productivity Growth without Technical Change in European Agriculture before 1850. Journal of Economic History 47(2), 419-432.

Clark, G. (2005). The Condition of the Working Class in England, 1209-2003. Journal of Political Economy 113(6), 1307-1340.

Cohen, D. and M. Soto (2007). Growth and human capital: good data, good results. Journal of Economic Growth 12(1), 51-76.

Coleman, D. C. (1983). Proto-Industrialization: A Concept Too Many. Economic History Review 36(3), 435-448.

Crafts, N. F. R. (1985). British Economic Growth During the Industrial Revolution. Oxford: Oxford University Press.

Crafts, N. F. R. (1996). The First Industrial Revolution: A Guided Tour for Growth Economists. American Economic Review Papers and Proceedings 86(2), 197-201.

Crafts, N. F. R. and K. Harley (1992). Output Growth and the British Industrial Revolution: A restatement of the Crafts-Harley View. Economic History Review 45, 703-730.

Crouzet, F. (1964). Wars, Blockade, and Economic Change in Europe, 1792-1815. Journal of Economic History 24, 567-588. 
Crouzet, F. (2003). The Historiography of French Economic Growth in the Nineteenth Century. Economic History Review 62(2), 215-242.

Darby, H. C. and H. Fullard (1970). The New Cambridge Modern History, Volume 14. Cambridge: Cambridge University Press.

Darnton, R. (1973). The Encyclopedie Wars of Prerevolutionary France. The American Historical Review 78(5), 1331-1352.

Darnton, R. (1979). The business of enlightenment: A publishing history of the Encyclopédie, 1775-1800. Cambridge, MA: Belknap-Harvard University Press.

Daudin, G. (2005). Commerce et prospérité: la France au XVIIIe siècle. Presses Paris Sorbonne.

Daudin, G. (2010). Domestic Trade and Market Size in Late-Eighteenth-Century France. The Journal of Economic History 70(3), 716-743.

de la Croix, D. and O. Licandro (2012). The Longevity of Famous People from Hammurabi to Einstein. CORE Discussion Paper 2012/52.

de Pleijt, A. M. and J. L. Weisdorf (2014). Human Capital Formation from Occupations: The 'Deskilling Hypothesis' Revisited. CGEH Working Paper 57.

de Tocqueville, A. (1856). The Old Regime and the French Revolution. Garden City, N.Y.: Doubleday. Reprinted in 1955.

Delefortrie, N. and J. Morice (1959). Les Revenus departmentaux en 1864 et en 1954. Paris, France: Colin.

DeLong, J. B. and A. Shleifer (1993). Princes and Merchants: City Growth before the Industrial Revolution. Journal of Law and Economics 36, 671-702.

Dittmar, J. E. (2011). Information Technology and Economic Change: The Impact of the Printing Press. Quarterly Journal of Economics 126, 1133-1172.

Dittmar, J. E. (2013). New Media, Firms, Ideas, and Growth: European Cities After Gutenberg. Working Paper.

Dowey, J. (2014). Mind over Matter: Access to Knowledge and the British Industrial Revolution. Ph. D. thesis, London School of Economics. Department of Economic History.

Dunham, A. L. (1955). The Industrial Revolution in France, 1815-1848. Exposition Press, New York.

FBTEE (2012). The French Book Trade in Enlightenemnt Europe Database.

Febvre, L. and H.-J. Martin (1958). L'Apparition du Livre. Paris: Albin Michel.

Fernihough, A. and K. H. O'Rourke (2014). Coal and the European Industrial Revolution. Oxford University Discussion Papers in Economic and Social History \#124.

Flora, P., F. Kraus, and W. Pfenning (1983). State, Economy, and Society in Western Europe 1815-1975: The Growth of Industrial Societies and Capitalist Economies, Volume 1. St. James Press, Chicago.

Fox, R. (1984). Presidential Address: Science, Industry, and the Social Order in Mulhouse, 1798-1871. The British Journal for the History of Science 17(2), 127-168.

Furet, F. and J. Ozouf (1977). Lire et écrire. L'alphabétisation des Français de Calvin à Judes Ferry. Minuit, Paris.

Galor, O. (2005). From Stagnation to Growth: Unified Growth Theory. In P. Aghion and S. Durlauf (Eds.), Handbook of Economic Growth, Volume 1, Chapter 4, pp. 171-293. Elsevier. 
Galor, O. (2011). Unified Growth Theory. Princeton University Press.

Gennaioli, N., R. La Porta, F. Lopez-de-Silanes, and A. Shleifer (2013). Human Capital and Regional Development. Quarterly Journal of Economics 128(1), 105-164.

Glaeser, E. L., R. La Porta, F. Lopez-de-Silanes, and A. Shleifer (2004). Do Institutions Cause Growth? Journal of Economic Growth 9(3), 271-303.

Glaeser, E. L., J. A. Scheinkman, and A. Shleifer (1995). Economic Growth in a Cross-Section of Cities. Journal of Monetary Economics 36(1), 117-143.

Goldin, C. and L. F. Katz (1998). The Origins of Technology-Skill Complementarity. Quarterly Journal of Economics 113(3), 693-732.

Goreaux, L. M. (1956). Les migrations agricoles en France depuis un siécle et leur relation avec certains facteurs économiques. Études et Conjoncture 11, 327-376.

Graham, H. (2011). Humble Petitioners? Seigneurial Courts, Royal Justice and the Role of Litigants in the Eighteenth Century. French History \& Civilization 4, 12-21.

Grantham, G. (1989). Agricultural Supply During the Industrial Revolution: French Evidence and European Implications. Journal of Economic History 49(1), 43-72.

Hall, R. E. and C. I. Jones (1999). Why Do Some Countries Produce So Much More Output Per Worker Than Others? Quarterly Journal of Economics 114(1), 83-116.

Hamscher, A. N. (2012). The Royal Financial Administration and the Prosecution of Crime in France, 1670-1789. Newark: University of Delaware Press.

Hansen, G. and E. Prescott (2002). Malthus to Solow. American Economic Review 92(4), 1205-1217.

Hanushek, E. A. and D. D. Kimko (2000). Schooling, Labor-Force Quality, and the Growth of Nations. American Economic Review 90(5), 1184-1208.

Hanushek, E. A. and L. Woessman (2012). Do Better Schools Lead to More Growth? Cognitive Skills, Economic Outcomes, and Causation. Journal of Economic Growth 17(4), 267-321.

Hanushek, E. A. and L. Woessmann (2008). The Role of Cognitive Skills in Economic Development. Journal of Economic Literature 46(3), 607-668.

Harris, J. H. (1998). Industrial Espionage and Technology Transfer: Britain and France in the Eighteenth Century. Aldershot: Ashgate.

Hau, M. (2012). The Invention of Enterprise: Entrepreneurship from Ancient Mesopotamia to Modern Times, Chapter Entrepreneurship in France, pp. 305-330. Princeton University Press.

Horn, J. (2006). The Path Not Taken: French Industrialization in the Age of Revolution, 1750-1830. Cambridge MA: MIT Press.

Horn, J. and M. C. Jacob (1998). Jean-Antoine Chaptal and the Cultural Roots of French Industrialization. Technology and Culture 39(4), 671-698.

Hornung, E. (2014). Immigration and the Diffusion of Technology: The Huguenot Diaspora in Prussia. American Economic Review 104(1), 84-122.

Houston, R. A. (1982). The Development of Literacy: Northern England, 1640-1750. Economic History Review 35(2), 199-216.

Huffman, W. and R. Evenson (2008). Science for Agriculture: A Long-Term Perspective. John Wiley \& 
Sons.

ISTC (2008). Incunabula Short-Title Catalogue. London: British Library.

Jacob, M. C. (1997). Scientific Culture and the Making of the Industrial West. New York: Oxford University Press.

Jacob, M. C. (2014). The First Knowledge Economy. Cambridge University Press.

Jedin, H., K. S. Latourette, and J. Martin (1970). Atlas Zur Kirchengeschichte. Freiburg: Herder.

Johnson, D. (1997). Agriculture and the Wealth of Nations. American Economic Review, Papers \& Proceedings $87(2), 1-12$.

Johnson, N. D. and M. Koyama (2014, February). Taxes, Lawyers, and the Decline of Witch Trials in France. Journal of Law and Economics 57, 77-112.

Jorgenson, D. W. and Z. Griliches (1967). The Explanation of Productivity Change. Review of Economic Studies 34(3), 249-283.

Kelly, M., J. Mokyr, and C. Ó Gráda (2014). Precocious Albion: A New Interpretation of the British Industrial Revolution. Annual Reviews of Economics 6. forthcoming.

Kessler, A. D. (2010). Marginalization and Myth: The Corporatist Roots of France's Forgotten Elective Judiciary. American Journal of Comparative Law 58, 679-720.

Komlos, J. (1998). Shrinking in a Growing Economy? The Mystery of Physical Stature during the Industrial Revolution. Journal of Economic History 58(3), 779-802.

Komlos, J. (2005). Height of French Soldiers, 1716-1784. [Computer file] ICPSR04363-v1.

Komlos, J. and J. Baten (1998). The Biological Standard of Living in Comparative Perspective. Franz Steiner, Stuttgart.

Krueger, A. B. and M. Lindahl (2001). Education for Growth: Why and for Whom? Journal of Economic Literature 39(4), 1101-1136.

Lemay, P. and R. E. Oesper (1948). Michel Eugéne Chevreul (1786-1889). Journal of Chemical Education 25(2), 62-70.

Livingstone, D. N. (2003). Putting Science in its Place: Geographies of Scientific Knowledge. Chicago University Press.

Lough, J. (1968). Essays on the Encyclopédie of Diderot and dŠAlembert. London: Oxford University Press.

Maddison, A. (2001). The World Economy. A Millennial Perspective. Paris: OECD.

Maddison, A. (2007). Historical Statistics. University of Groningen. Webpage: http://www.ggdc.net/maddison/.

Mankiw, N. G., D. Romer, and D. N. Weil (1992). A Contribution to the Empirics of Economic Growth. Quarterly Journal of Economics 107(2), 407-37.

Marczewski, J. (1961). Some Aspects of the Economic Growth of France 1660-1958. Economic Development and Cultural Change 9(3), 369-386.

Mathias, P. (1972). Science and Society 1600-1900, Chapter Who Unbound Prometheus?, pp. 54-81. Cambridge University Press. 
McClellan, J. E. (1985). Science Reorganized: Scientific Societies in the Eighteenth Century. New York: Columbia University Press.

McEvedy, C. and R. Jones (1978). Atlas of World Population History, Facts on File. New York.

Meisenzahl, R. and J. Mokyr (2012). The Rate and Direction of Invention in the British Industrial Revolution: Incentives and Institutions. In J. Lerner and S. Stern (Eds.), The Rate and Direction of Inventive Activity Revisited, Chapter 9, pp. 443-479. Chicago: University of Chicago Press.

Mendels, F. F. (1972). Proto-industrialization: The First Phase of the Industrialization Process. Economic History Review 32(1), 241-261.

Mitch, D. (1993). The Role of Human Capital in the First Industrial Revolution. In J. Mokyr (Ed.), The British Industrial Revolution: An Economic Perspective, pp. 267-307. Boulder: Westview.

Mokyr, J. (1976). Industrialization in the Low Countries, 1795-1850. Yale University Press.

Mokyr, J. (1990). The Lever of Riches. Oxford: Oxford University Press.

Mokyr, J. (2000). Knowledge, Technology, and Economic Growth During the Industrial Revolution. In B. V. Ark and G. Kuper (Eds.), Technology and Productivity Growth. Hague: Kluwert. Available at http://faculty.wcas.northwestern.edu/ jmokyr/Groningen.pdf.

Mokyr, J. (2002). The Gifts of Athena: Historical Origins of the Knowledge Economy. Princeton, NJ: Princeton University Press.

Mokyr, J. (2005a). Long-Term Economic Growth and the History of Technology. Volume 1 of Handbook of Economic Growth, pp. 1113-80. Elsevier, Amsterdam.

Mokyr, J. (2005b). The Intellectual Origin of Modern Economic Growth. Journal of Economic History 65(2), 285-351.

Mokyr, J. (2010). The Enlightened Economy: An Economic History of Britain 1700-1850. Yale University Press.

Mokyr, J. and C. Ó Gráda (1996). Height and Health in the United Kingdom 1815-1860: Evidence from the East India Company Army. Explorations in Economic History 33(2), 141-168.

Mokyr, J. and H.-J. Voth (2009). Understanding Growth in Early Modern Europe. In S. Broadberry and K. O'Rourke (Eds.), The Cambridge Economic History of Europe. Cambridge: Cambridge University Press.

Moser, P. (2005). How Do Patent Laws Influence Innovation? Evidence from Nineteenth-Century World's Fairs. American Economic Review 95(4), 1214-1236.

Moser, P. (2012). Innovation without Patents: Evidence from World's Fairs. Journal of Law and Economics 55(1), 43-74.

Mours, S. (1958). Les Églises Réformées en France. Tableaux et Cartes. Librairie Protestante.

Mousnier, R. (1979). The Institutions of France Under the Absolute Monarchy, 1598-1789, Volume 2. University of Chicago Press.

Muessig, U. (2012). Judges and Judging in the History of the Common Law and Civil Law, Chapter Superior courts in early-modern France, England and the Holy Roman Empire, pp. 209-233. Cambridge University Press.

Murphy, T. E. (2010). Old Habits Die Hard (Sometimes): What can Département Heterogeneity Tell us 
about the French Fertility Decline? IGIER Working Paper 364.

Musson, A. E. and E. Robinson (1969). Science and Technology in the Industrial Revolution. Manchester University Press.

Nelson, R. R. and E. S. Phelps (1966). Investment in Humans, Technological Diffusion, and Economic Growth. American Economic Review 56(2), 69-75.

Nicholas, S. J. and J. M. Nicholas (1992). Male Literacy, "Deskilling", and the Industrial Revolution. The Journal of Interdisciplinary History 23(1), 1-18.

North, D. C. (1981). Structure and Change in Economic History. New York: W. W. Norton.

North, D. C. and R. P. Thomas (1973). The Rise of the Western World: A New Economic History. Cambridge UK: Cambridge University Press.

Nunn, N. and N. Qian (2011). The Potato's Contribution to Population and Urbanization: Evidence from an Historical Experiment. Quarterly Journal of Economics 126(2), 593-650.

Nuvolari, A. and V. Tartari (2011). Bennet Woodcroft and the value of English patents, 1617-1841. Explorations in Economic History 48, 97-115.

O'Brien, P. and C. Keyder (1978). Economic Growth in Britain and France, 1780-1914: Two Paths to the 20th Century. London: Allen and Unwin.

O'Rourke, K. H., A. S. Rahman, and A. M. Taylor (2013). Luddites, the Industrial Revolution, and the Demographic Transition. Journal of Economic Growth 18, 373-409. NBER working paper 14484.

O'Rourke, K. H. and J. G. Williamson (1995). Education, Globalization and Catch-up: Scandinavia in the Swedish Mirror. Scandinavian Economic History Review 43(3), 287-309.

Pomeranz, K. (2000). The Great Divergence: China, Europe, and the Making of the modern World Economy. Princeton, N.J.: Princeton University Press.

Roche, D. (1998). France in the Enlightenment. Harvard University Press, Cambridge, MA.

Roehl, R. (1976). French Industrialization: A Reconsideration. Explorations in Economic History 13, 223-281.

Rostow, W. W. (1975). How it All Began: Origins of the Modern Economy. Methuen and Co., London.

Sandberg, L. G. (1979). The Case of the Impoverished Sophisticate: Human Capital and Swedish Economic Growth before World War I. Journal of Economic History 39(1), 225-241.

Scheewe, W. (2000). Nurturing the Soil-feeding the People. Rex Bookstore, Inc.

Scoville, W. C. (1953). The Huguenots in the French Economy, 1650-1750. Quarterly Journal of Economics 67(3), 423-444.

Smil, V. (1997). Global Population and the Nitrogen Cycle. Scientific American 277(1), 76-81.

Smith, J. M. (2006a). The French Nobility in the Eighteenth Century: Reassessments and New Approaches. University Park, Pa.: Pennsylvania State University Press.

Smith, M. S. (2006b). The Emergence of Modern Business Enterprise in France, 1800-1930. Harvard University Press.

Sprandel, R. (1968). Das Eisengewerbe im Mittelalter. A. Hiersemann.

Statistique Général de France (1851). Recensement 1851. 
Statistique Général de France (1861). Statistique Industrielle.

Statistique Général de France (1878). Annuaire Statistique de la France. Paris, Imprimerie Nationale.

Steckel, R. H. (1983). Height and Per Capita Income. Historical Methods 16, 1-7.

Steckel, R. H. (2008). Biological Measures of the Standard of Living. Journal of Economic Perspectives 22(1), 129-152.

Taylor, A. M. (1999). Sources of Convergence in the Late Nineteenth Century. European Economic Review 43(9), 1621-1645.

Tilly, C. (1990). Coercion, Capital, and European States, 990-1990. London: Blackwell.

Vandenbussche, J., P. Aghion, and C. Meghir (2006). Growth, Distance to Frontier and Composition of Human Capital. Journal of Economic Growth 11(2), 97-127.

Verley, P. (1985). La Révolution Industrielle. MA Editions, Paris.

Vogt, W. P. (1982). Paideia for Profit. History of Education Quarterly 22(1), 89-98.

Voigtländer, N. and H.-J. Voth (2012). Persecution Perpetuated: The Medieval Origins of Anti-Semitic Violence in Nazi Germany. Quarterly Journal of Economics 127(3), 1339-1392.

Watts, G. (1952). The Encyclopédie and the Descriptions des arts et métiers. The French Review 25(6), 444-454.

Wrigley, E. A. (1988). Continuity, Chance and Change: The Character of the Industrial Revolution in England. Cambridge: CUP. 


\section{FIGURES}

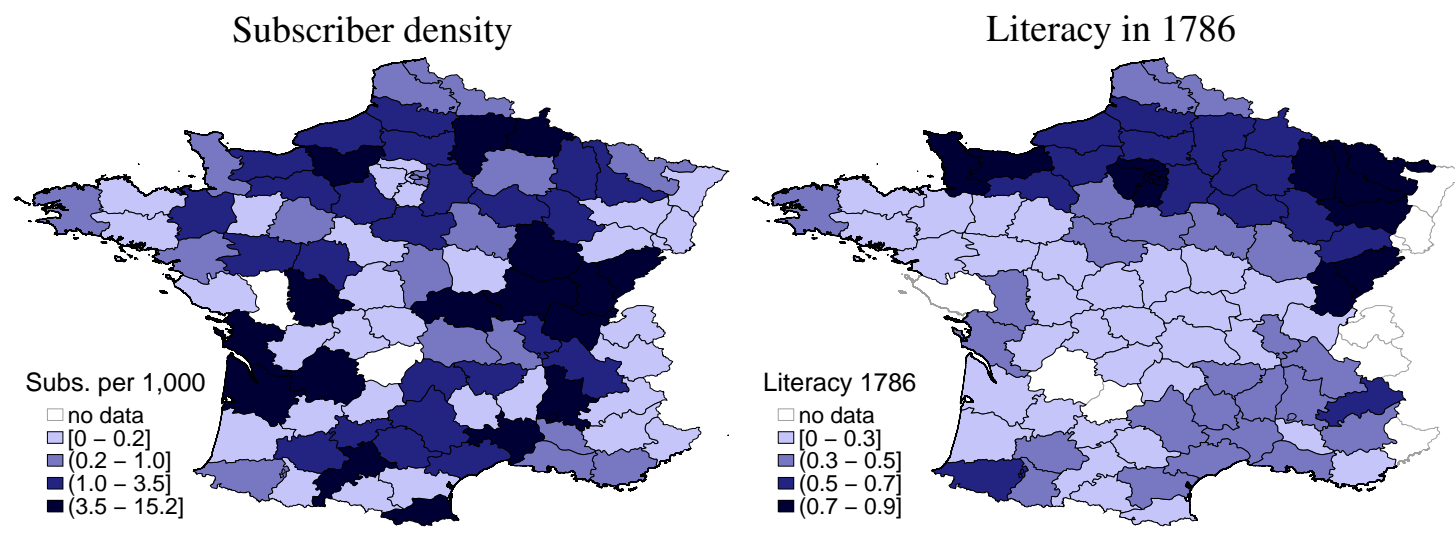

Figure 1: Encyclopédie subscriber density and literacy rates

Notes: The left panel shows the spatial distribution of Encyclopédie subscribers per 1,000 city inhabitants in the second half of the 18th century. The right panel shows the distribution of literacy rates (percentage of males signing their marriage certificate) across French departments in 1786. Both variables are described in detail in Section 3.1. Figure C.4 in the Appendix plots the two variables against each other, showing that they are not correlated. 


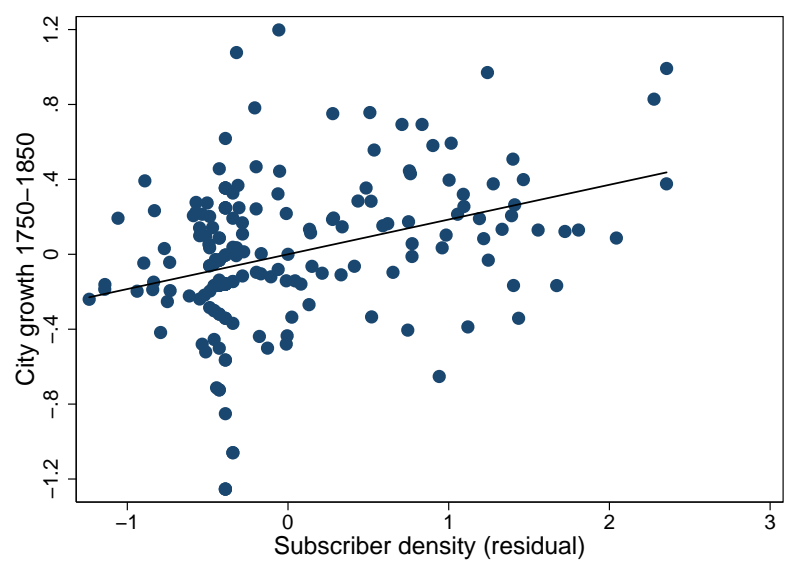

Figure 2: Encyclopédie subscriptions and city growth, 1750-1850

Notes: The figure plots average annual population growth of French cities against Encyclopédie subscriber density (lnSubDens), after controlling for our baseline and early knowledge controls (listed in Table 1).

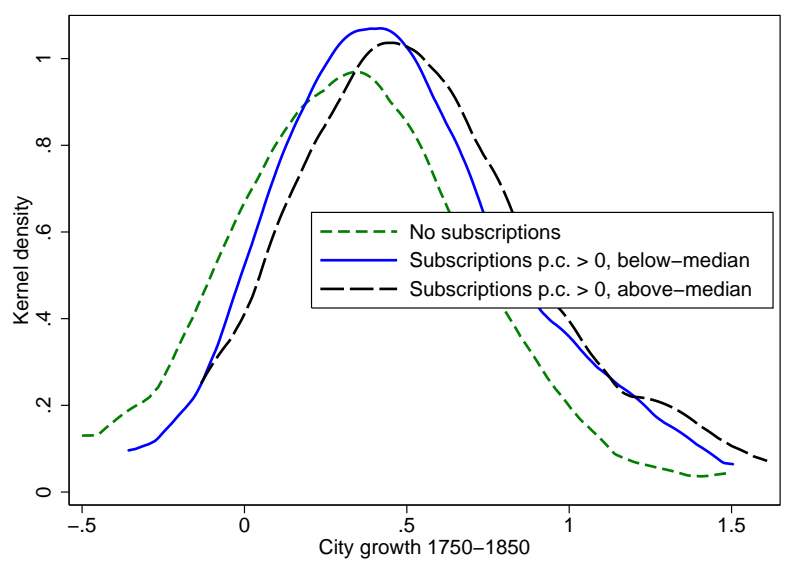

Figure 3: Subscriptions and city growth, 1750-1850

Notes: The figure shows the Kernel density of city population growth over the period 1750-1850 for three subsets of French cities: 108 cities without Encyclopédie subscriptions, as well as 43 (42) cities with subscriptions and belowmedian (above-median) subscriber density. 


\section{TABLES}

Table 1: Correlations with subscriber density $(\ln S u b D e n s)$

\begin{tabular}{|c|c|c|c|c|c|c|}
\hline & (1) & (2) & & (3) & $(4)^{\ddagger}$ & $(5)^{\ddagger}$ \\
\hline Cities included: & All & Subs $>0$ & Cities/Dept. included: & All & All & Subs $>0$ \\
\hline \multicolumn{3}{|c|}{ Panel A: Baseline Controls } & \multicolumn{4}{|c|}{ Panel C: Worker skills } \\
\hline $\ln ($ Population 1750) & $\begin{array}{c}0.374^{* * *} \\
(0.073)\end{array}$ & $\begin{array}{c}-0.234^{* *} \\
(0.110)\end{array}$ & Literacy $1686^{\dagger}$ & $\begin{array}{c}0.551 \\
(0.593)\end{array}$ & $\begin{array}{c}0.905 \\
(0.650)\end{array}$ & $\begin{array}{c}0.026 \\
(0.777)\end{array}$ \\
\hline Atlantic Port & $\begin{array}{c}0.081 \\
(0.207)\end{array}$ & $\begin{array}{c}-0.222 \\
(0.213)\end{array}$ & Literacy $1786^{\dagger}$ & $\begin{array}{c}0.290 \\
(0.345)\end{array}$ & $\begin{array}{c}0.358 \\
(0.323)\end{array}$ & $\begin{array}{c}0.054 \\
(0.383)\end{array}$ \\
\hline Mediterranean Port & $\begin{array}{c}0.022 \\
(0.276)\end{array}$ & $\begin{array}{l}-0.129 \\
(0.223)\end{array}$ & School Rate $1837^{\dagger}$ & $\begin{array}{c}0.363 \\
(0.350)\end{array}$ & $\begin{array}{c}0.313 \\
(0.335)\end{array}$ & $\begin{array}{c}0.200 \\
(0.412)\end{array}$ \\
\hline \multirow[t]{2}{*}{ Navigable River } & $0.422^{* *}$ & -0.167 & & & & \\
\hline & $(0.202)$ & $(0.210)$ & \multicolumn{4}{|c|}{ Panel D: Additional Controls } \\
\hline \multirow[t]{2}{*}{ Non French-Speaking } & $\begin{array}{c}-0.376^{* *} \\
(0.146)\end{array}$ & $\begin{array}{c}-0.719^{* *} \\
(0.297)\end{array}$ & lnSTNBooksDens & $\begin{array}{c}0.242^{* * *} \\
(0.041)\end{array}$ & $\begin{array}{c}0.194^{* * *} \\
(0.050)\end{array}$ & $\begin{array}{c}0.062 \\
(0.056)\end{array}$ \\
\hline & & & \multirow[t]{2}{*}{ Pays d'Eléction } & 0.046 & 0.137 & 0.048 \\
\hline \multicolumn{3}{|c|}{ Panel B: Early Knowledge Controls } & & $(0.129)$ & $(0.128)$ & $(0.205)$ \\
\hline University & $\begin{array}{c}1.030^{* * *} \\
(0.186)\end{array}$ & $\begin{array}{c}0.316 \\
(0.194)\end{array}$ & $\operatorname{lnPreIndDens}{ }^{\dagger}$ & $\begin{array}{c}-0.027 \\
(0.830)\end{array}$ & $\begin{array}{c}-0.033 \\
(0.829)\end{array}$ & $\begin{array}{c}-0.546 \\
(0.846)\end{array}$ \\
\hline Printing Press & $\begin{array}{c}0.712^{* * *} \\
(0.170)\end{array}$ & $\begin{array}{c}0.203 \\
(0.182)\end{array}$ & InDistanceCoal & $\begin{array}{c}-0.173^{* *} \\
(0.083)\end{array}$ & $\begin{array}{l}-0.104 \\
(0.083)\end{array}$ & $\begin{array}{c}0.025 \\
(0.106)\end{array}$ \\
\hline $\ln ($ Books Printed 1500) & $\begin{array}{c}0.171^{* * *} \\
(0.061)\end{array}$ & $\begin{array}{c}0.039 \\
(0.066)\end{array}$ & lnNoblesDens ${ }^{\dagger}$ & $\begin{array}{c}0.233 \\
(0.278)\end{array}$ & $\begin{array}{c}0.253 \\
(0.301)\end{array}$ & $\begin{array}{c}0.736^{* * *} \\
(0.249)\end{array}$ \\
\hline
\end{tabular}

Notes: The table shows the coefficients of individual regressions of subscriber density, $\ln S u b D e n s$, on a variety of city characteristics. $\ln S u b D e n s$ is our baseline measure for local density of subscribers to the Quarto edition of the Encyclopédie, computed as described in Section 3.1. Population 1750 measures urban population (in thousands) for the cities in our sample. Atlantic Port, Mediterranean Port and Navigable River are dummies for cities with ports on the Atlantic Ocean or on the Mediterranean Sea, or located on a navigable river. Non French Speaking is a dummy for cities in six French departments that spoke a language other than French in the 18th century. University is a dummy for cities that hosted a University before 1750. Printing Press is a dummy for cities where a printing press was established before 1500. $\ln$ (Books Printed 1500) represents the log number of editions printed before 1501. Literacy in 1686 and 1786 measures the percentage of men signing their wedding certificate in the respective year. School Rate in 1837 measures the ratio of students to school-age population (5 to 15 years) in 1836-37. InSTNBooksDens represents the ( $\log$ ) book purchases per capita from the Swiss publishing house Société Typographique de Neuchâtel (STN) over the period 1769-1794. Pays d'élection is a dummy for cities in regions where the French king exerted particularly strong control over tax collection. InPreIndDens is an index of pre-industrial activities in France that includes the number of mines, forges, iron trading locations, and textile manufactures before 1500. InDistanceCoal measures the log distance (in $\mathrm{km}$ ) from the closest coal field mined in the 19th century. InNoblesDens reflects the (log) number of noble families per capita in each French department. For sources and details, see Section C.4. Robust standard errors in parentheses. $* \mathrm{p}<0.1, * * \mathrm{p}<0.05, * * * \mathrm{p}<0.01$.

$\dagger$ Variable observed at the department level, and corresponding regression also run at department level.

${ }^{\ddagger}$ Regressions include baseline and early knowledge controls. 
Table 2: Matching estimation by city size and location Dependent variable: log city growth over the indicated period

\begin{tabular}{|c|c|c|c|c|c|c|}
\hline & (1) & (2) & (3) & (4) & (5) & (6) \\
\hline & \multicolumn{4}{|c|}{ Period 1750-1850 } & \multicolumn{2}{|c|}{$1700-1750$} \\
\hline City size percentiles incl.: & All & $10-90 \mathrm{pct}$ & All & $10-90 \mathrm{pct}$ & All & $10-90 \mathrm{pct}$ \\
\hline$I_{S u b s>0}$ & $\begin{array}{c}0.146^{* *} \\
(0.07)\end{array}$ & $\begin{array}{c}0.155^{* *} \\
(0.07)\end{array}$ & $\begin{array}{c}0.267^{* * *} \\
(0.07)\end{array}$ & $\begin{array}{c}0.163^{* *} \\
(0.07)\end{array}$ & $\begin{array}{l}0.087 \\
(0.06)\end{array}$ & $\begin{array}{l}0.063 \\
(0.05)\end{array}$ \\
\hline $\begin{array}{l}\text { Matching variables } \\
\text { Population } \\
\text { Location }\end{array}$ & $\checkmark$ & $\checkmark$ & $\begin{array}{l}\checkmark \\
\checkmark\end{array}$ & $\begin{array}{l}\checkmark \\
\checkmark\end{array}$ & $\begin{array}{l}\checkmark \\
\checkmark\end{array}$ & $\begin{array}{l}\checkmark \\
\checkmark\end{array}$ \\
\hline Observations & 177 & 154 & 167 & 144 & 129 & 110 \\
\hline
\end{tabular}

Notes: All regressions are run by propensity score matching at the city level, excluding non-French speaking cities and city growth outliers (the top and bottom 1\%), and using the three nearest neighbors. Average treatment of the treated (ATT) effects are reported, where the treatment variable is the indicator $I_{S u b s>0}$, which takes on value 1 if a city had above-zero subscriptions to the Encyclopédie. Columns 1 and 2 in panel A use city population as matching variable. Columns 3-6 add geographic longitude and latitude (location) as matching variables. Standard errors in parentheses. $* \mathrm{p}<0.1, * * \mathrm{p}<0.05, * * * \mathrm{p}<0.01$. 
Table 3: Encyclopédie subscriptions and city growth

Dependent variable: $\log$ city growth, 1750-1850

\begin{tabular}{|c|c|c|c|c|c|c|c|c|}
\hline & (1) & (2) & (3) & $\begin{array}{c}\text { (4) } \\
\text { incl. dummy }\end{array}$ & $\begin{array}{c}(5) \\
\text { subs }>0\end{array}$ & $\begin{array}{c}\text { (6) } \\
\text { unweighted }\end{array}$ & $\begin{array}{c}(7) \\
\text { no } \log \end{array}$ & $\begin{array}{c}(8) \\
1700-1750\end{array}$ \\
\hline Subs. Density $^{\dagger}$ & $\begin{array}{l}0.100^{* *} \\
(0.039)\end{array}$ & $\begin{array}{c}0.171^{* * *} \\
(0.036)\end{array}$ & $\begin{array}{c}0.169^{* * *} \\
(0.033)\end{array}$ & $\begin{array}{c}0.132^{* * *} \\
(0.043)\end{array}$ & $\begin{array}{l}0.117^{* *} \\
(0.045)\end{array}$ & $\begin{array}{c}0.204^{* * *} \\
(0.036)\end{array}$ & $\begin{array}{c}0.040^{* * *} \\
(0.008)\end{array}$ & $\begin{array}{c}0.008 \\
(0.037)\end{array}$ \\
\hline $\ln$ Pop $_{\text {initial }}$ & $\begin{array}{c}0.055^{* * *} \\
(0.014)\end{array}$ & $\begin{array}{c}-0.085^{* *} \\
(0.041)\end{array}$ & $\begin{array}{l}-0.089^{*} \\
(0.048)\end{array}$ & $\begin{array}{c}-0.130^{* * *} \\
(0.047)\end{array}$ & $\begin{array}{c}-0.150^{* * *} \\
(0.053)\end{array}$ & $\begin{array}{c}-0.156^{* * *} \\
(0.051)\end{array}$ & $\begin{array}{l}-0.071 \\
(0.049)\end{array}$ & $\begin{array}{l}-0.058 \\
(0.040)\end{array}$ \\
\hline Atlantic Port & & $\begin{array}{c}0.221^{* * *} \\
(0.082)\end{array}$ & $\begin{array}{l}0.242^{* *} \\
(0.094)\end{array}$ & $\begin{array}{l}0.253^{* *} \\
(0.099)\end{array}$ & $\begin{array}{l}0.214^{*} \\
(0.120)\end{array}$ & $\begin{array}{l}0.349^{* *} \\
(0.162)\end{array}$ & $\begin{array}{c}0.253^{* * *} \\
(0.090)\end{array}$ & $\begin{array}{c}0.087 \\
(0.101)\end{array}$ \\
\hline Mediterranean Port & & $\begin{array}{c}0.779^{* * *} \\
(0.076)\end{array}$ & $\begin{array}{c}0.794^{* * *} \\
(0.091)\end{array}$ & $\begin{array}{c}0.823^{* * *} \\
(0.083)\end{array}$ & $\begin{array}{c}0.883^{* * *} \\
(0.093)\end{array}$ & $\begin{array}{c}0.752^{* * *} \\
(0.142)\end{array}$ & $\begin{array}{c}0.824^{* * *} \\
(0.102)\end{array}$ & $\begin{array}{c}-0.203^{* *} \\
(0.094)\end{array}$ \\
\hline Navigable River & & $\begin{array}{c}0.095 \\
(0.068)\end{array}$ & $\begin{array}{c}0.068 \\
(0.072)\end{array}$ & $\begin{array}{c}0.075 \\
(0.071)\end{array}$ & $\begin{array}{c}0.089 \\
(0.090)\end{array}$ & $\begin{array}{c}0.134^{*} \\
(0.069)\end{array}$ & $\begin{array}{c}0.081 \\
(0.073)\end{array}$ & $\begin{array}{c}0.001 \\
(0.076)\end{array}$ \\
\hline Paris & & $\begin{array}{c}0.575^{* * *} \\
(0.136)\end{array}$ & $\begin{array}{c}0.610^{* * *} \\
(0.132)\end{array}$ & $\begin{array}{c}0.617^{* * *} \\
(0.130)\end{array}$ & $\begin{array}{c}0.574^{* * *} \\
(0.145)\end{array}$ & $\begin{array}{c}0.760^{* * *} \\
(0.171)\end{array}$ & $\begin{array}{c}0.614^{* * *} \\
(0.130)\end{array}$ & $\begin{array}{l}-0.020 \\
(0.135)\end{array}$ \\
\hline Non French Speaking & & $\begin{array}{c}0.337^{* * *} \\
(0.089)\end{array}$ & $\begin{array}{c}0.330^{* * *} \\
(0.097)\end{array}$ & $\begin{array}{c}0.281^{* * *} \\
(0.107)\end{array}$ & $\begin{array}{c}0.184 \\
(0.118)\end{array}$ & $\begin{array}{c}0.428^{* * *} \\
(0.145)\end{array}$ & $\begin{array}{c}0.328^{* * *} \\
(0.093)\end{array}$ & $\begin{array}{c}0.100 \\
(0.129)\end{array}$ \\
\hline University & & & $\begin{array}{l}-0.063 \\
(0.067)\end{array}$ & $\begin{array}{l}-0.050 \\
(0.065)\end{array}$ & $\begin{array}{l}-0.011 \\
(0.073)\end{array}$ & $\begin{array}{l}-0.123 \\
(0.084)\end{array}$ & $\begin{array}{l}-0.056 \\
(0.066)\end{array}$ & $\begin{array}{c}0.122^{*} \\
(0.069)\end{array}$ \\
\hline Printing Press in 1500 & & & $\begin{array}{c}0.093 \\
(0.094)\end{array}$ & $\begin{array}{c}0.057 \\
(0.090)\end{array}$ & $\begin{array}{c}-0.023 \\
(0.106)\end{array}$ & $\begin{array}{c}0.188^{*} \\
(0.098)\end{array}$ & $\begin{array}{c}0.119 \\
(0.091)\end{array}$ & $\begin{array}{c}-0.078 \\
(0.083)\end{array}$ \\
\hline $\ln ($ Books Printed 1500$)$ & & & $\begin{array}{c}-0.001 \\
(0.020)\end{array}$ & $\begin{array}{c}0.012 \\
(0.020)\end{array}$ & $\begin{array}{c}0.026 \\
(0.022)\end{array}$ & $\begin{array}{c}0.006 \\
(0.025)\end{array}$ & $\begin{array}{c}-0.012 \\
(0.020)\end{array}$ & $\begin{array}{c}0.029^{*} \\
(0.017)\end{array}$ \\
\hline$I_{S u b s>0}$ & & & & $\begin{array}{c}0.134 \\
(0.089)\end{array}$ & & & & \\
\hline $\mathrm{R}^{2}$ & 0.12 & 0.36 & 0.36 & 0.37 & 0.48 & 0.27 & 0.35 & 0.17 \\
\hline Observations & 193 & 193 & 193 & 193 & 85 & 193 & 193 & 148 \\
\hline \multicolumn{9}{|c|}{ Magnitude: subscriber density } \\
\hline $0-75$ percentile & $\begin{array}{l}0.188^{* *} \\
{[0.011]}\end{array}$ & $\begin{array}{c}0.323^{* * *} \\
{[0.000]}\end{array}$ & $\begin{array}{c}0.320^{* * *} \\
{[0.000]}\end{array}$ & $\begin{array}{c}0.384^{* * *} \\
{[0.000]}\end{array}$ & $\begin{array}{l}0.221^{* *} \\
{[0.012]}\end{array}$ & $\begin{array}{l}0.387^{* * *} \\
{[0.000]}\end{array}$ & $\begin{array}{c}0.226^{* * *} \\
{[0.000]}\end{array}$ & $\begin{array}{c}0.016 \\
{[0.822]}\end{array}$ \\
\hline beta coeff. Subs. Density & 0.213 & 0.365 & 0.362 & - & 0.286 & 0.347 & 0.340 & 0.027 \\
\hline
\end{tabular}

Notes: All regressions are run at the city level and are weighted (except for column 6) by initial population of the respective period. The dependent variable is log city population growth over the period 1750-1850, except for column 8 , which analyzes 1700-50. For details on the control variables, see the notes to Table 1. Robust standard errors in parentheses. $* \mathrm{p}<0.1, * * \mathrm{p}<0.05, * * * \mathrm{p}<0.01$.

${ }^{\dagger}$ Subs. Density represents two measures of city-level subscriber density to the Quarto edition of the Encyclopédie: SubDens in column 7, and lnSubDens in all other columns. Both are computed as described in Section 3.1.

$¥$ The "Magnitude" panel reports two statistics for the size of the relationship between subscriber density and city population growth: "0-75 percentile" corresponds to the log population growth differential between cities with zero subscribers, as compared to those with subscriber density in the 75th percentile (among cites with above-zero subscribers). In column 4, this effect includes $I_{S u b s>0} ; \mathrm{p}$-values in square brackets. The last row reports the standardized beta coefficient for the respective Subs. Density measure. 
Table 4: Panel regressions with city population, 1500-1850

Dependent variable: $\log$ city population

\begin{tabular}{lccccccc}
\hline \hline & $(1)$ & $(2)$ & $(3)$ & $(4)$ & $(5)$ & $(6)$ & $(7)$ \\
& \multicolumn{2}{c}{ Full panel, 1500-1850 } & \multicolumn{2}{c}{ Balanced panel } & \multicolumn{2}{c}{ Placebo periods } \\
& & & & $1500-1850$ & $1700-1850$ & $y=1600$ & $y=1700$ \\
\hline lnSubDens $\times$ Post $_{1750}$ & $0.106^{* * *}$ & $0.136^{* * *}$ & $0.103^{* *}$ & $0.164^{* *}$ & $0.123^{* * *}$ & $0.146^{* * *}$ & $0.158^{* * *}$ \\
& $(0.029)$ & $(0.031)$ & $(0.044)$ & $(0.070)$ & $(0.045)$ & $(0.029)$ & $(0.033)$ \\
& & & & & & -0.039 & -0.043 \\
& & & & & & $(0.077)$ & $(0.044)$ \\
Controls & & $\checkmark$ & $\checkmark$ & $\checkmark$ & $\checkmark$ & $\checkmark$ & $\checkmark$ \\
Additional Controls & & & $\checkmark$ & & & & $\checkmark$ \\
City FE & $\checkmark$ & $\checkmark$ & $\checkmark$ & $\checkmark$ & $\checkmark$ & $\checkmark$ & $\checkmark$ \\
Time Period FE & $\checkmark$ & $\checkmark$ & $\checkmark$ & $\checkmark$ & $\checkmark$ & $\checkmark$ & $\checkmark$ \\
\hline $\mathrm{R}^{2}$ & 0.86 & 0.87 & 0.88 & 0.85 & 0.94 & 0.88 & 0.87 \\
Observations & 846 & 846 & 722 & 270 & 592 & 846 & 846 \\
\hline \hline
\end{tabular}

Notes: All regressions are run at the city level. The dependent variable is the log of city population in the years 1500 , $1600,1700,1750,1800$, and 1850 . The Post $_{1750}$ indicator variable takes value zero for the periods 1500-1750, and value one for 1800 and 1850. Post $y$ is defined similarly, but with respect to the placebo period $y$ indicated in columns 6 and 7. "Controls" include a dummy for Paris as well as the baseline controls and early knowledge controls listed in Table 1, which also lists the "Additional Controls." All controls are interacted with Post ${ }_{1750}$, and, where applicable, also with Post ${ }_{y}$. Robust standard errors in parentheses (clustered at the department level in column 3 ). $* \mathrm{p}<0.1, * *$ $\mathrm{p}<0.05, * * * \mathrm{p}<0.01$. 
Table 5: Literacy and additional controls

Dependent variable: $\log$ city growth, $1750-1850$

\begin{tabular}{lcccc}
\hline \hline & $(1)$ & $(2)$ & $(3)$ & $(4)$ \\
\hline lnSubDens & $0.180^{* * *}$ & $0.198^{* * *}$ & $0.194^{* * *}$ & $0.154^{* * *}$ \\
& $(0.040)$ & $(0.042)$ & $(0.042)$ & $(0.051)$ \\
Literacy 1786 & -0.209 & -0.156 & -0.240 & $-0.276^{*}$ \\
& $(0.142)$ & $(0.135)$ & $(0.149)$ & $(0.148)$ \\
InSTNBooksDens & & -0.025 & -0.023 & -0.020 \\
& & $(0.021)$ & $(0.022)$ & $(0.022)$ \\
lnPreIndDens & & & $0.985^{* *}$ & $0.916^{* *}$ \\
& & & $(0.399)$ & $(0.398)$ \\
InDistanceCoal & & & 0.025 & 0.034 \\
& & & $(0.047)$ & $(0.045)$ \\
Pays d'Eléction & & & -0.060 & -0.074 \\
& & & $(0.075)$ & $(0.073)$ \\
lnNoblesDens & & & 0.145 & 0.104 \\
& & & $(0.111)$ & $(0.114)$ \\
$I_{\text {Subs }>0}$ & & & & 0.142 \\
In(Pop 1750) & $-0.075^{*}$ & -0.053 & -0.025 & $-0.099)$ \\
& $(0.043)$ & $(0.041)$ & $(0.050)$ & $(0.051)$ \\
Controls & $\checkmark$ & $\checkmark$ & $\checkmark$ & $\checkmark$ \\
\hline $\mathrm{R}^{2}$ & 0.38 & 0.39 & 0.41 & 0.42 \\
Observations & 166 & 166 & 164 & 164 \\
\hline \hline
\end{tabular}

Notes: All regressions are run at the city level, include a dummy for Paris, and are weighted by city population in 1750. The dependent variable is log city population growth in 1750-1850. "Controls" include the baseline controls and early knowledge controls listed in Table 1 . For details on the explanatory variables see notes to Table 1 . Standard errors (clustered at the department level) in parentheses. ${ }^{*} \mathrm{p}<0.1,{ }^{*} \mathrm{p}<0.05, * * * \mathrm{p}<0.01$. 
Table 6: Soldier height

Dependent variable: Soldier height in $\mathrm{cm}$ in the indicated period

\begin{tabular}{lcc|cc|cc}
\hline \hline & $(1)$ & $(2)$ & $(3)$ & $(4)$ & $(5)$ & $(6)$ \\
Period & \multicolumn{2}{c}{$1819-1826$} & \multicolumn{2}{c|}{ pre-1750 } & \multicolumn{2}{c}{$1819-1826$} \\
\hline InSubDens & $0.416^{* * *}$ & $0.450^{* * *}$ & 0.113 & 0.117 & $0.362^{* *}$ & $0.421^{* * *}$ \\
& $(0.136)$ & $(0.129)$ & $(0.116)$ & $(0.117)$ & $(0.139)$ & $(0.130)$ \\
Literacy 1786 & $2.805^{* * *}$ & $3.056^{* * *}$ & & & & \\
& $(0.398)$ & $(0.360)$ & & & & \\
Literacy 1686 & & & $1.050^{* *}$ & $0.994^{*}$ & $1.749^{* *}$ & $1.516^{*}$ \\
& & & $(0.527)$ & $(0.550)$ & $(0.851)$ & $(0.827)$ \\
Change in literacy 1686-1786 & & & & & $3.043^{* * *}$ & $4.165^{* * *}$ \\
& & & & & $(1.007)$ & $(0.763)$ \\
Height pre-1750 & & & & & $0.408^{*}$ & 0.192 \\
& & & & & $(0.210)$ & $(0.145)$ \\
Baseline Controls & & $\checkmark$ & & $\checkmark$ & & $\checkmark$ \\
\hline $\mathrm{R}^{2}$ & 0.42 & 0.60 & 0.06 & 0.16 & 0.49 & 0.65 \\
Observations & 77 & 77 & 75 & 75 & 74 & 74 \\
\hline \hline
\end{tabular}

Notes: All regressions are run at the department level and include a dummy for Paris (Department Seine). The dependent variable in columns 1-2 and 5-6 is soldier height in 1819-26. In columns 3-4, the dependent variable is average soldier height recorded over the period 1716-49. To account for variation in height and soldier age within this period, we control for age, age squared, and birth decade (see Appendix C.3 for detail). Sources for the dependent variables are listed in Section 4.2. "Baseline Controls" are those listed in Table 1. For details on $\ln S u b D e n s$, literacy, and controls see the notes to Table 1. Robust standard errors in parentheses. ${ }^{*} \mathrm{p}<0.1, * * \mathrm{p}<0.05, * * * \mathrm{p}<0.01$.

Table 7: Disposable income, industrial activity, and wages around 1850

\begin{tabular}{lccccc}
\hline \hline & $(1)$ & $(2)$ & $(3)$ & $(4)$ & $(5)$ \\
$\begin{array}{l}\text { Dependent var. } \\
\text { (all in logs) }\end{array}$ & $\begin{array}{c}\text { Disp. income } \\
\text { p.c. in 1864 }\end{array}$ & $\begin{array}{c}\text { Ind. Output } \\
\text { p.c. in 1861 }\end{array}$ & $\begin{array}{c}\text { Ind. Employm. } \\
\text { p.c. in 1861 }\end{array}$ & \multicolumn{2}{c}{ Wages (1852) } \\
Industry & Agric. \\
\hline lnSubDens & $0.068^{* *}$ & $0.215^{*}$ & $0.156^{*}$ & $0.055^{* * *}$ & 0.040 \\
& $(0.030)$ & $(0.110)$ & $(0.091)$ & $(0.017)$ & $(0.026)$ \\
School Rate 1837 & $0.225^{* *}$ & $0.871^{* *}$ & $0.833^{* *}$ & $0.203^{* * *}$ & $0.413^{* * *}$ \\
& $(0.111)$ & $(0.361)$ & $(0.339)$ & $(0.056)$ & $(0.084)$ \\
Baseline Controls & $\checkmark$ & $\checkmark$ & $\checkmark$ & $\checkmark$ & $\checkmark$ \\
\hline $\mathrm{R}^{2}$ & 0.33 & 0.18 & 0.16 & 0.48 & 0.51 \\
Observations & 87 & 87 & 87 & 79 & 79 \\
\hline \hline
\end{tabular}

Notes: All regressions are run at the French department level and include a dummy for Paris (Department Seine). "Baseline Controls" are those listed in Table 1. For details on lnSubDens and controls see the notes to Table 1. Sources for the dependent variables are listed in Section 4.2. Robust standard errors in parentheses. $* \mathrm{p}<0.1, * *$ $\mathrm{p}<0.05, * * * \mathrm{p}<0.01$. 
Table 8: Scientific societies, Descriptions des Arts et Métiers, and city growth Dependent variable: $\log$ city growth over the indicated period

\begin{tabular}{|c|c|c|c|c|c|}
\hline & $(1)$ & $(2)$ & (3) & (4) & $(5)$ \\
\hline Variable $x$ : & \multicolumn{3}{|c|}{ pre-1750 Scientific Societies } & \multirow{2}{*}{\multicolumn{2}{|c|}{$\begin{array}{c}\text { Desc. Arts et Métiers } \\
1750-1850\end{array}$}} \\
\hline Period: & 1750 & 1850 & $1700-1750$ & & \\
\hline \multicolumn{6}{|c|}{ Panel A: Matching estimation, based on indicator } \\
\hline$I_{x>0}$ & $\begin{array}{l}0.204^{* *} \\
(0.098)\end{array}$ & $\begin{array}{l}0.193^{* *} \\
(0.095)\end{array}$ & $\begin{array}{c}0.028 \\
(0.083)\end{array}$ & $\begin{array}{c}0.193^{* *} \\
0.082\end{array}$ & $\begin{array}{l}0.140 \\
0.096\end{array}$ \\
\hline \multicolumn{6}{|c|}{ Matching variables } \\
\hline Population & $\checkmark$ & $\checkmark$ & $\checkmark$ & $\checkmark$ & $\checkmark$ \\
\hline Location & & $\checkmark$ & $\checkmark$ & & $\checkmark$ \\
\hline Observations & 185 & 175 & 136 & 177 & 167 \\
\hline \multicolumn{6}{|c|}{ Panel B: OLS, based on per capita members (cols 1-3) / sales (cols 4-5) } \\
\hline $\ln \operatorname{Density}(x)$ & $\begin{array}{c}0.285^{* * *} \\
(0.083)\end{array}$ & $\begin{array}{l}0.295^{* *} \\
(0.126)\end{array}$ & $\begin{array}{c}0.041 \\
(0.098)\end{array}$ & $\begin{array}{c}0.533^{* * *} \\
(0.167)\end{array}$ & $\begin{array}{l}0.460^{* *} \\
(0.208)\end{array}$ \\
\hline$I_{x>0}$ & & $\begin{array}{l}-0.010 \\
(0.130)\end{array}$ & & & $\begin{array}{c}0.048 \\
(0.086)\end{array}$ \\
\hline Controls & $\checkmark$ & $\checkmark$ & $\checkmark$ & $\checkmark$ & $\checkmark$ \\
\hline $\mathrm{R}^{2}$ & 0.34 & 0.34 & 0.22 & 0.32 & 0.32 \\
\hline Observations & 158 & 158 & 118 & 166 & 166 \\
\hline
\end{tabular}

Notes: All regressions are run at the city level. The dependent variable is log city population growth over the period indicated in the header. In panel A, all regressions are run by propensity score matching as described in Table 2. In columns 1-3, the treatment variable is the indicator $I_{x}>0$ that takes on value 1 if a city hosted a scientific society before 1750 (the eight cities in our sample where scientific societies were founded after 1750 are excluded). In columns 4-5, the indicator $I_{x}>0$ takes on value 1 if a city had sales of the Descriptions des Arts et Métiers. Columns 1 and 4 use city population as matching variable. Columns 2,3 , and 5 add geographic longitude and latitude (location) as matching variables. In panel B, all regressions are run by OLS and are weighted by initial population of the respective period. "Controls" include the baseline controls and the early knowledge controls listed in Table 1 (column 3 controls for initial population in 1700 instead of 1750). In addition, all specifications include literacy (in 1686 for column 3 and in 1786 for all other columns) and a dummy for Paris. For further detail see the notes to Table 1. Standard errors (clustered at the department level in all regressions in panel B) in parentheses.* $\mathrm{p}<0.1, * * \mathrm{p}<0.05,{ }^{* * *} \mathrm{p}<0.01$. 
Table 9: Subscriber density, professionals in science, and exhibits

\begin{tabular}{|c|c|c|c|c|c|c|c|c|}
\hline \multirow{3}{*}{$\begin{array}{l}\text { Dep. Variables } \\
\text { (local density of) }\end{array}$} & (1) & (2) & (3) & (4) & \multirow{3}{*}{\multicolumn{2}{|c|}{$\begin{array}{l}(5) \\
\text { Science Prof., } 1851 \\
\text { (dept. level) }\end{array}$}} & (7) & (8) \\
\hline & \multicolumn{4}{|c|}{ Famous Scientists 1000-1887 } & & & \multicolumn{2}{|c|}{ Exhibitors, 1851} \\
\hline & \multicolumn{2}{|c|}{ by birth city } & \multicolumn{2}{|c|}{ by death city } & & & & \\
\hline lnSubDens & $\begin{array}{c}0.107^{* * *} \\
(0.024)\end{array}$ & $\begin{array}{c}0.125^{* * *} \\
(0.033)\end{array}$ & $\begin{array}{c}0.073^{* * *} \\
(0.023)\end{array}$ & $\begin{array}{c}0.070^{* * *} \\
(0.019)\end{array}$ & $\begin{array}{l}0.120^{* *} \\
(0.051)\end{array}$ & $\begin{array}{c}0.147^{* * *} \\
(0.054)\end{array}$ & $\begin{array}{l}0.023^{* *} \\
(0.011)\end{array}$ & $\begin{array}{l}0.021^{*} \\
(0.011)\end{array}$ \\
\hline Baseline Controls & & $\checkmark$ & & $\checkmark$ & & $\checkmark$ & & $\checkmark$ \\
\hline $\mathrm{R}^{2}$ & 0.09 & 0.20 & 0.08 & 0.22 & 0.12 & 0.39 & 0.19 & 0.32 \\
\hline Observations & 193 & 166 & 193 & 166 & 84 & 78 & 193 & 165 \\
\hline
\end{tabular}

Notes: All regressions include a dummy for Paris. Regressions in columns 1-4 and 7-8 are run at the city level, and those in columns 5-6, at the department level. The "local density" of the dependent variables is defined as $\ln (1+$ dep.var/population). In columns 1-2 and 3-4, dep.var is famous scientists per capita by city of birth and city of death, respectively. These are people listed in the Index Bio-Bibliographicus Notorum Hominum whose profession is related to science, mathematics, chemistry, physics, or medicine. The data are from de la Croix and Licandro (2012). In columns 5-6, dep.var is the number of people in professions related to science (medicine and hommes de lettres et savants) from the 1851 Recensement. In columns 7-8, dep.var is innovations from French cities exhibited at the London world fair (Crystal Palace Exhibition) in 1851. These data are from Moser (2005). "Baseline Controls" are those listed in Table 1. In columns 2, 4, 6, and 8 we also control for literacy in 1786, and in columns 6 and 8 we also control for the share of employment in industry in 1861. Standard errors (clustered at the department level in columns 2,4 , and 8) in parentheses. $* \mathrm{p}<0.1, * * \mathrm{p}<0.05, * * * \mathrm{p}<0.01$.

Table 10: Huguenots, subscriber density, and city growth

\begin{tabular}{|c|c|c|c|c|c|c|}
\hline \multirow{3}{*}{ Dep. Var.: } & \multirow{3}{*}{$\begin{array}{c}(1) \\
\ln S u b D e n s\end{array}$} & \multirow{3}{*}{$\begin{array}{c}(2) \\
\text { Literacy }_{1786}\end{array}$} & (3) & (4) & (5) & (6) \\
\hline & & & \multicolumn{4}{|c|}{ Log City Growth } \\
\hline & & & \multicolumn{2}{|c|}{$1750-1850$} & \multicolumn{2}{|c|}{$1700-1750$} \\
\hline $\operatorname{lnHugDens} s_{1670}$ & $\begin{array}{c}0.590^{* * *} \\
(0.168)\end{array}$ & $\begin{array}{l}-0.058 \\
(0.060)\end{array}$ & $\begin{array}{l}0.197^{* *} \\
(0.077)\end{array}$ & $\begin{array}{c}0.070 \\
(0.089)\end{array}$ & $\begin{array}{l}-0.039 \\
(0.074)\end{array}$ & $\begin{array}{l}-0.060 \\
(0.069)\end{array}$ \\
\hline InSubDens & & & & $\begin{array}{c}0.216^{* * *} \\
(0.055)\end{array}$ & & $\begin{array}{c}0.035 \\
(0.039)\end{array}$ \\
\hline Baseline Controls & $\checkmark$ & $\checkmark$ & $\checkmark$ & $\checkmark$ & $\checkmark$ & $\checkmark$ \\
\hline $\mathrm{R}^{2}$ & 0.20 & 0.06 & 0.15 & 0.25 & 0.04 & 0.04 \\
\hline Observations & 163 & 150 & 163 & 163 & 132 & 132 \\
\hline
\end{tabular}

Notes: All regressions are run at the city level and include a dummy for Paris. For details on $\ln S u b D e n s$ and "Baseline Controls" see Table 1 (columns 5-6 control for initial population in 1700 instead of 1750). lnHugDens 1670 is the $(\log )$ number of Huguenots in 1670 relative to population at the department level. Standard errors (clustered at the department level) in parentheses. $* \mathrm{p}<0.1, * * \mathrm{p}<0.05, * * * \mathrm{p}<0.01$. 
Table 11: Subscriber density and average local firm productivity in 1839-47

Dep. Var.: log wages (by sector and arrondissement)

\begin{tabular}{lcccccc}
\hline \hline & $(1)$ & $(2)$ & $(3)$ & $(4)$ & $(5)$ & $(6)$ \\
\hline InSubDens & $0.043^{* * *}$ & $0.042^{* * *}$ & $0.033^{* *}$ & 0.022 & 0.017 & \\
lnSubsDens & $(0.016)$ & $(0.016)$ & $(0.014)$ & $(0.015)$ & $(0.022)$ & \\
& $0.063^{* * *}$ & $0.051^{* * *}$ & $0.046^{* * *}$ & $0.059^{* * *}$ & $0.062^{* * *}$ & $0.058^{* * *}$ \\
School Rate 1837 & $(0.015)$ & $(0.015)$ & $(0.016)$ & $(0.017)$ & $(0.018)$ & $(0.019)$ \\
& $0.247^{* * *}$ & $0.232^{* * *}$ & $0.240^{* * *}$ & $0.163^{* *}$ & & \\
School $\times$ Modern & $(0.070)$ & $(0.072)$ & $(0.072)$ & $(0.069)$ & & \\
& -0.028 & -0.037 & -0.041 & -0.011 & 0.010 & 0.046 \\
Establishment Size & $(0.069)$ & $(0.067)$ & $(0.070)$ & $(0.091)$ & $(0.099)$ & $(0.109)$ \\
& $0.055^{* * *}$ & $0.045^{* * *}$ & $0.042^{* * *}$ & $0.046^{* * *}$ & $0.041^{* * *}$ & $0.038^{* * *}$ \\
Size $\times$ Modern & $(0.008)$ & $(0.008)$ & $(0.009)$ & $(0.010)$ & $(0.010)$ & $(0.010)$ \\
& $-0.069^{* * *}$ & $-0.033^{* * *}$ & $-0.030^{* *}$ & $-0.031^{*}$ & $-0.035^{* *}$ & $-0.034^{* *}$ \\
Modern Sector & $(0.011)$ & $(0.011)$ & $(0.014)$ & $(0.016)$ & $(0.015)$ & $(0.016)$ \\
& $0.132^{* * *}$ & & & & & \\
Sector FE & $(0.036)$ & & & & & $\checkmark$ \\
Baseline Controls & & $\checkmark$ & $\checkmark$ & $\checkmark$ & $\checkmark$ & $\checkmark$ \\
Additional Controls & & & $\checkmark$ & $\checkmark$ & $\checkmark$ & $\checkmark$ \\
Department FE & & & & $\checkmark$ & $\checkmark$ & $\checkmark$ \\
Arrondissement FE & & & & & $\checkmark$ & $(\checkmark)$ \\
\hline R & & & & & $\checkmark$ \\
Observations & 0.13 & 0.22 & 0.35 & 0.37 & 0.49 & 0.58 \\
\hline \hline
\end{tabular}

Notes: All regressions are run at the arrondissement level and include a dummy for Paris (Department Seine). The dependent variable is the log of average male wages across all firms in a sector $j$ in arrondissement $n$. There are more than 14,000 firms in the sample (see Appendix D.5). Firms are classified into 8 sectors, and the 4 most innovative ones are categorized as "modern" (see Appendix Section D.5 and Table D.16 for detail). Establishment size is the $(\log )$ average number of workers across all firms in $j$ and $n$. "Baseline Controls" and "Additional Controls" are those listed in Table 1; we also control for (log) total department-level population and urbanization rates (both in 1831) to capture agglomeration effects. For each control variable, both its level and its interaction with "modern" is included. For details on $\ln S u b D e n s$ and controls see the notes to Table 1. Original city-level variables are aggregated to the arrondissement level as described in Appendix C.5. Standard errors (clustered at the department level) in parentheses. $* \mathrm{p}<0.1, * * \mathrm{p}<0.05, * * * \mathrm{p}<0.01$. 
Table 12: Subscriber density and firm productivity within individual industries

\begin{tabular}{|c|c|c|c|c|c|}
\hline \multirow{3}{*}{ Sector Name } & \multirow{3}{*}{$\begin{array}{c}(1) \\
\text { Sector } \\
\text { type }\end{array}$} & \multirow{3}{*}{$\begin{array}{c}(2) \\
\text { Coefficient } \\
\text { lnSubDens }\end{array}$} & \multirow{3}{*}{$\begin{array}{l}(3) \\
\mathrm{R}^{2} \\
\text { Obs. }\end{array}$} & \multirow{2}{*}{\multicolumn{2}{|c|}{$\begin{array}{c}(4) \\
\text { Engines per } 1,000\end{array}$}} \\
\hline & & & & & \\
\hline & & & & Steam & Others \\
\hline Transportation Equipment & modern & $\begin{array}{l}0.115^{* * *} \\
(0.026)\end{array}$ & $\begin{array}{c}0.65 \\
38\end{array}$ & 2 & 9 \\
\hline $\begin{array}{l}\text { Printing Technology, and } \\
\text { Scientific Instruments }\end{array}$ & modern & $\begin{array}{l}0.103^{* * *} \\
(0.021)\end{array}$ & $\begin{array}{l}0.20 \\
221\end{array}$ & 1 & 26 \\
\hline Textile and Clothing & modern & $\begin{array}{l}0.060^{* * *} \\
(0.017)\end{array}$ & $\begin{array}{l}0.27 \\
303\end{array}$ & 3 & 8 \\
\hline Furniture and Lighting & modern & $\begin{array}{l}0.056^{*} \\
(0.033)\end{array}$ & $\begin{array}{l}0.54 \\
75\end{array}$ & 13 & 1 \\
\hline Leather & old & $\begin{array}{l}0.047^{* *} \\
(0.023)\end{array}$ & $\begin{array}{l}0.19 \\
165\end{array}$ & 3 & 46 \\
\hline Metal and Metal Products & old & $\begin{array}{l}0.045^{*} \\
(0.024)\end{array}$ & $\begin{array}{l}0.17 \\
273\end{array}$ & 6 & 34 \\
\hline Mining & old & $\begin{array}{l}0.040^{* *} \\
(0.018)\end{array}$ & $\begin{array}{l}0.31 \\
187\end{array}$ & 3 & 15 \\
\hline Ceramics and Glass & old & $\begin{array}{c}0.003 \\
(0.020)\end{array}$ & $\begin{array}{l}0.27 \\
167\end{array}$ & 4 & 5 \\
\hline
\end{tabular}

Notes: For each sector, column 1 specifies whether the sector belongs to the "modern" or "old" manufacturing classification, reflecting its "inventive output" (see Section 5.3 and Appendix D.5 for detail). Sectors are ranked by the size of the coefficient on lnSubDens, reported in column 2; this coefficient is obtained by regressing - within each sector - log male wages (the dependent variable in Table 11) on InSubDens, average establishment size, the urbanization rate, and the baseline controls listed in Table 1. For each regression, column 3 reports the $\mathrm{R}^{2}$ and the number of observations. Standard errors (clustered at the department level) in parentheses. $* \mathrm{p}<0.1, * * \mathrm{p}<0.05, * * * \mathrm{p}<0.01$. Columns 4-5 show the sector-specific average number of steam engines and other engines per 1,000 workers (see Appendix D.5 for detail). 